\title{
A Unique Isolation of a Lytic Bacteriophage Infected Bacillus anthracis Isolate from Pafuri, South Africa
}

\author{
Ayesha Hassim ${ }^{1, *}$, Kgaugelo Edward Lekota ${ }^{1,2}$, David Schalk van Dyk ${ }^{3}$, Edgar Henry Dekker ${ }^{3}$ \\ and Henriette van Heerden 1 (D) \\ 1 Department of Veterinary Tropical diseases, University of Pretoria, Faculty of Veterinary Science, \\ Pretoria 0110, South Africa; lekotae@gmail.com (K.E.L); Henriette.VanHeerden@up.ac.za (H.v.H.) \\ 2 Unit for Environmental Sciences and Management: Microbiology, North-West University, Potchefstroom \\ Campus, Private Bag X6001, Potchefstroom 2520, South Africa \\ 3 Department of Agriculture Fisheries and Forestry, Office of the State Veterinarian, \\ Skukuza 1350, South Africa; SchalkVD@nda.agric.za (D.S.v.D.); Atd@nda.agric.za (E.H.D.) \\ * Correspondence: ayesha.hassim@gmail.com; Tel.: +27-125-298-339
}

Received: 30 April 2020; Accepted: 11 June 2020; Published: 20 June 2020

\begin{abstract}
Bacillus anthracis is a soil-borne, Gram-positive endospore-forming bacterium and the causative agent of anthrax. It is enzootic in Pafuri, Kruger National Park in South Africa. The bacterium is amplified in a wild ungulate host, which then becomes a source of infection to the next host upon its death. The exact mechanisms involving the onset (index case) and termination of an outbreak are poorly understood, in part due to a paucity of information about the soil-based component of the bacterium's lifecycle. In this study, we present the unique isolation of a dsDNA bacteriophage from a wildebeest carcass site suspected of having succumbed to anthrax. The aggressively lytic bacteriophage hampered the initial isolation of B. anthracis from samples collected at the carcass site. Classic bacteriologic methods were used to test the isolated phage on B. anthracis under different conditions to simulate deteriorating carcass conditions. Whole genome sequencing was employed to determine the relationship between the bacterium isolated on site and the bacteriophage-dubbed Bacillus phage Crookii. The 154,012 bp phage belongs to Myoviridae and groups closely with another African anthrax carcass-associated Bacillus phage WPh. Bacillus phage Crookii was lytic against B. cereus sensu lato group members but demonstrated a greater affinity for encapsulated B. anthracis at lower concentrations $\left(<1 \times 10^{8} \mathrm{pfu}\right)$ of bacteriophage. The unusual isolation of this bacteriophage demonstrates the phage's role in decreasing the inoculum in the environment and impact on the life cycle of $B$. anthracis at a carcass site.
\end{abstract}

Keywords: bacteriophage infection; Myoviridae; anthrax; Bacillus anthracis; soil ecology; pathogen-bioremediation

\section{Introduction}

Bacillus anthracis is a soil-borne, Gram-positive endospore-forming bacterium and the causative agent of the disease known as anthrax [1,2]. Anthrax is endemic in Kruger National Park (KNP), South Africa where outbreaks are cyclical among wildlife [3-5]. Anthrax is a zoonosis, but predominantly affects wild ungulates in the KNP [6,7]. Bacillus anthracis has a monomorphic genome that is closely related to other members of the B. cereus sensu lato group, specifically B. cereus and B. thuringiensis. Most of the genetic variation of these organisms occurs on their respective plasmids and pathogenicity islands which code for the toxins [8-10]. The plasmids of B. anthracis are pX01, which encodes for the lethal factor and edema factor [11,12], and pX02 that encodes for encapsulation [13]. There are also four putative lambdoid prophages that set $B$. anthracis apart from its close relatives [14]. 
While the transmission, dissemination, and conditions of persistence for B. anthracis during anthrax outbreaks have been well described over the past few decades $[2,4,15,16]$, little is known about the bacterium's activity in the soil during outbreak dormancy $[17,18]$. There have been several theories that are variations on Van Ness' "incubator area" hypothesis [19] over the decades [2]. It is believed that the bacteria are capable of replicating within biofilms in the soil and rhizospheres of plants [17,20]. Schuch and Fischetti [18] proposed an alternate cycle of the bacterium in the biofilms of earthworm guts, mediated by bacteriophages and serving as replication sites. There is however a dearth of such environmental data from active anthrax outbreaks. Many of these theories focus on bacterial replication in the environment with less attention on the marked concentration decay of the inoculum over time.

Bacteriophages are viruses that infect bacteria. These viruses belong to the order Caudovirales with members of the Siphoviridae, Podoviridae, Myoviridae, and Tectiviridae families [21-23]. They have two pathways to replication within the bacterium: lysogeny and lysis. Lysogeny involves viral integration into the host genome, while lysis activates the host machinery to propagate its progeny. Ultimately, both pathways lead to bacterial lysis [23-25]. The difference between the two phage types is marked by the phage-encoded influences on the bacterium. Lysogenic bacteriophages have been theorized to impact bacterial lifecycles through fitness traits such as antibiotic resistance, replication efficiency, and sporulation rates of bacteria $[18,26]$. Bacteriophages have been useful tools for decades as a medium for diagnostics in microbiology, vectors in molecular biology, as well as in phage therapy applications $[27,28]$. The $\gamma$-phage is one such example used to identify B. anthracis in routine diagnostics [24,29]. The more popular focus for study in recent years has been in the evaluation of lytic bacteriophage endolysins as an alternative means of disinfection as well as therapy mediums in an age of dwindling antibiotic options [28,30,31]. In this study, we explore the role of a lytic bacteriophage in outbreak dynamics, as naturally occurring pathogen disinfectant agents while the phage propagates, using the example of a wildebeest (Connochaetes taurinus) carcass site during an anthrax outbreak in South Africa.

\section{Materials and Methods}

The carcass remnants of a juvenile wildebeest (carcass \# DS201579) was discovered on the 24th of February 2015 in Crooks Corner, Pafuri, KNP, South Africa. Approximately 75\% of the carcass had already been consumed by vultures. White backed vultures (Gyps africanus) fed in large numbers and disrupt the carcass site a great deal during feeding. Generally, there is soil all over the carcass remnants. Blood smears, a swab (from the orbital socket) and soil samples (from the clearing where extravasation fluid marked the ground) were collected from the carcass site for diagnostics at the Skukuza State Veterinary Research Laboratory (SSRL) as part of the Skukuza State Veterinary Services Disease Surveillance System.

\subsection{Isolation}

The blood smear was Giemsa stained [2,32] and evaluated microscopically. The smear showed low level evidence of spores and the possible vestiges of encapsulated square ended B. anthracis vegetative cells. Since an anthrax outbreak was underway in the area at the time, the swab and soil were submitted for bacteriologic diagnostics of anthrax using selective and non-selective media. The swab was (i) directly streaked onto 5\% impala blood agar (BA) and polymyxin EDTA-thallous acetate agar (PET; PLET excluding lysozyme) and then (ii) heat treated in a $100 \mu \mathrm{L}$ phosphate buffered saline (PBS) at 65 ${ }^{\circ} \mathrm{C}$ for $30 \mathrm{~min}$, thereafter it was similarly streaked onto the blood and PET agars and incubated at $37^{\circ} \mathrm{C}$ overnight. One gram of soil was added to $9 \mathrm{~mL}$ PBS, shaken for $3 \mathrm{~h}$, heat treated at $65^{\circ} \mathrm{C}$ for $30 \mathrm{~min}$, serial diluted (to $1 \times 10^{-8}$ ), and then similarly plated out onto PET and BA media in triplicate for each dilution [2].

After the incubation, only the heat-treated BA plate produced two colonies $(<5 \mathrm{~mm}$ in diameter) while the 2 PET agar plates and 1 BA plate from the direct streaking still appeared sterile. The colonies were sub-cultured and demonstrated sensitivity to $10 \mu \mathrm{g}$ penicillin discs (Oxoid, United Kingdom) and 
diagnostic $\gamma$-phage. The single colonies were sub-cultured five more times thereafter until an opaque grey-white colony morphology was obtained (without any observed turbidity between 5-8 h post incubation) and then stored in glycerol. Other Bacillus spp. isolated on the media were also stored and identified.

The 2 PET and 1 BA plates (with sterile appearance) were then each flushed with $500 \mu \mathrm{L}$ PBS and filtered through a $0.2 \mu \mathrm{m}$ cellulose acetate membrane (Lasec, South Africa). A BA plate was divided into two with B. anthracis 34F2 Sterne strain plated onto the one half and B. anthracis DS201579 strain plated out onto the other. Ten microliters of the filtrate was dropped into the center of each half of the lawn area and the plate tilted in the dilution streak method [27] then incubated at $37^{\circ} \mathrm{C}$ overnight.

The filtrate, dubbed "Crookii," was evaluated for plaque titers, in plaque-forming units (pfu), using the double layer agar method without the use of antibiotics $[27,33]$ with B. anthracis DS201579 strain as the host and a 10 fold dilution series of the filtrate with five replicates for each dilution. Ten microliters of bacteriophage filtrate at each of the 10-fold dilution series was tested on the bacterial lawns of B. subtilis ATCC ${ }^{\circledR}$ 6633 ${ }^{\mathrm{TM}}$ (used as standard laboratory control), B. cereus ATCC ${ }^{\circledR} 33019^{\mathrm{TM}}$, B. thuringiensis (lab strain -Pafuri) and B. mycoides (lab strain -Pafuri).

\subsection{Viral Precipitation}

Viral precipitation was achieved by dissolving $2.3 \%$ sodium chloride and $7 \%$ weight/volume polyethylene glycol 6000 (PEG6000) (Merck Millipore) into the filtrate and refrigerated overnight at $4{ }^{\circ} \mathrm{C}$. The viscous solution was then centrifuged at $3000 \times \mathrm{g}$ for $60 \mathrm{~min}$ at $4{ }^{\circ} \mathrm{C}$. The viral pellet was dissolved to a final volume of $1 \mathrm{~mL}$ in phage buffer containing $100 \mathrm{mM}$ calcium chloride $\left(\mathrm{CaCl}_{2}\right)$, magnesium sulphate $\left(\mathrm{MgSO}_{4} \bullet 7 \mathrm{H}_{2} \mathrm{O}\right), 50 \mathrm{mM}$ Tris- $\mathrm{Cl}(1 \mathrm{M}, \mathrm{pH}$ 7.5), and distilled water. Half the precipitate was submitted for transmission electron micrograph (TEM) while the other underwent DNA extraction.

\subsection{Transmission Electron Micrograph}

The TEM was performed at the Electron Microscope Unit of the University of Pretoria, Faculty of Veterinary Science using negative staining with $2 \%$ uranyl acetate.

\subsection{The Effect of Viral Propagation on B. anthracis DS201579}

To determine the effect of the bacteriophage Bacillus phage Crookii on B. anthracis under different conditions (simulating carcass nutrient conditions), $1 \mathrm{~mL}$ of cattle blood was inoculated with 500 spores of B. anthracis Sterne and B. anthracis DS201579 and $20 \mu \mathrm{L}$ of Crookii at $5 \times 10^{8} \mathrm{pfu} / \mathrm{mL}$ were incubated under standard atmospheric conditions or with $8 \%$ carbon dioxide at $37^{\circ} \mathrm{C}$ overnight in a shaking incubator. Replicates included $0.8 \% \mathrm{w} / \mathrm{v}$ of $\left(\mathrm{NaHCO}_{3}\right)$ sodium bicarbonate. A third set of positive control blood tubes included B. anthracis Sterne and $\gamma$-phage at $5 \times 10^{8} \mathrm{pfu} / \mathrm{mL}$, under the same conditions, in parallel. Blood smears (five slides for each set) were made with $20 \mu \mathrm{L}$ of blood at $8 \mathrm{~h}$, then $12 \mathrm{~h}$ and at $24 \mathrm{~h}$. These smears were immediately fixed in methanol, stained with Romanowsky-Giemsa for $30 \mathrm{~min}$ [32] and examined at 1000x magnification. A 100 microscopic fields across a $100 \mu \mathrm{L}$ of blood for each set of conditions were visually appraised and directly counted to reflect cell proliferation. The blood smear analyses were aimed at determining if sporulation is triggered as a defense mechanism against phage infection [26,34] or in response to nutrient availability [35]. Since there are multiple variables to consider, figures illustrating the descriptive statistics of the vegetative cell and spore counts were generated in R Console version 3.2.1 [36].

The DNA from B. anthracis DS201579 strain was isolated using High Pure Template Preparation $\mathrm{Kit}^{\circledR}$ (Roche) using the Gram-positive bacterial protocol with $20 \mathrm{mg} / \mathrm{mL}$ Lysozyme L6876 (Sigma Aldrich). The viral DNA was isolated from propagated lysates through the phenol-chloroform isoamyl alcohol method from phage lysate at a concentration of $9 \times 10^{11} \mathrm{pfu} / \mathrm{mL}[37,38]$. 


\subsection{High-Throughput Sequencing}

Shotgun library preparations of the B. anthracis and Bacillus phage Crookii were performed using the Nextera XT DNA Sample Prep Kit (Illumina, USA) by following the manufacturer's instructions. Sequencing was performed on the Illumina MiSeq sequencing platform (Illumina) using the MiSeq Reagent Kit v3 (600 cycle).

\subsubsection{Bioinformatics Analysis}

The quality of the sequenced $300 \mathrm{bp}$ paired end reads of the B. anthracis DS201579 and Bacillus phage Crookii were assessed using FASTQC software version 0:10.1 [39]. Adaptors and ambiguous nucleotides sequences were trimmed using CLC Genomic Workbench 7.5.1. The reads were quality trimmed to an average length of $288 \mathrm{bp}$. Sequence read mapping analysis of the B. anthracis DS201579 reads was performed on CLC Genomic Workbench 7.5.1 using B. anthracis Ames Ancestor (NC_007530.2; NC_007322.2 and NC_007323,2) as a reference. Unmapped reads from the read-mapping analysis were collected and de novo assembled using CLC Genomic Workbench. The de novo assemblies of the B. anthracis DS201579 were carried out using CLC Genomic workbench 7.5.1. The assembled contigs of the bacterium were aligned with BLASTn [40] using B. anthracis Ames Ancestor (NC_007530.2; NC_007322.2 and NC_007323,2) as a reference genome. The progressive Mauve tool [41] was used to re-order the assembled contigs using B. anthracis Ames ancestor genome. Prophage regions were predicted using PHAge Search Tool Enhanced Release (PHASTER) [42].

De novo assembly of the Bacillus phage Crookii was also carried out using CLC Genomic Workbench 7.5.1. BLASTn was used to determine the closest sequence identity to Bacillus phage Crookii [40]. The CGView comparative tool [43] was used to compare the Bacillus phage Crookii genome sequence to Bacillus phage WPh. Phylogenetic analysis of the bacteriophage was performed to identify and classify Bacillus phage Crookii. The phage major capsid protein coding gene sequence ( 1,430 bp) was extracted from the assembled genome of Bacillus phage Crookii. The sequence was used to mine for the other closely related phage sequences using BLAST homology searchers from NCBI. Multiple alignments of the extracted gene sequences were performed using MAFFT 7 [44]. Maximum likelihood analysis of the Bacillus phage Crookii and related Bacillus phage sequences were performed using 1000 bootstrap replications in MEGA 7 [45]. The assembled contigs of B. anthracis DS201579 and Bacillus phage Crookii were annotated using the NCBI Prokaryotic Genome Annotation Pipeline (PGAP) [46] and Rapid Annotation using Subsystem Technology (RAST) [47] respectively.

\subsubsection{Nucleotide Sequence Accession Numbers}

The genomes of B. anthracis DS201579 and Bacillus phage Crookii have been deposited in GenBank under the accession numbers LVWF00000000 (includes complete pX02 accession CM008136) and KU847400 respectively.

\section{Results}

While the same protocols were used as per the standard operating procedures of the veterinary laboratory, SSRL; it is important to highlight that the first few attempts at isolation from the samples at this carcass site resulted in sterile media. This was true for both the selective media plates and the 5\% BA plates after 24-h incubations. The successive attempts on the same samples (that yielded an isolate as described below) were pursued because of the observation of (i) "ghost cells" and spores on the Giemsa stained blood smears, (ii) the visual evidence from the carcass site and (iii) the proximity to other anthrax positive carcasses in the area during an active outbreak.

\subsection{Isolation}

Two colonies (i.e., total of $2 \mathrm{CFU}$ from the heat treated swab) on BA plate had a greyish-white, rough, domed morphology and were sensitive to penicillin and $\gamma$-phage. This preliminarily identified 
the bacterial isolates to be $B$. anthracis $[2,48]$. When a whole plate of a single colony was streaked out, it took on a turbid appearance after $8 \mathrm{~h}$ and thereafter developed large plaques $(\geq 10 \mathrm{~mm}$ in diameter $)$ in the lawn.

The soil sample failed to produce any B. anthracis isolates at any of the dilutions, despite heat treatment. The plates were also conspicuous for the absence of $B$. cereus colonies which are normally abundant in soil samples from Pafuri. There was, however, a consistence of $B$. subtilis on all the plates with $B$. mycoides featuring on only the plates from the lower dilution series $\left(\leq 1 \times 10^{-3}\right)$. Bacillus spp. were identified using classic bacteriologic methods at the Bacteriology Laboratory of the Department of Veterinary Tropical Diseases, Faculty of Veterinary Science, University of Pretoria.

The filtrate that was placed in the center of the B. anthracis Sterne 34F2 and DS201579 bacterial lawns demonstrated clear lytic zones at the deposit sites (Figure 1). The dilution streak at the edge of the plate demonstrated a smaller lysis zone for Sterne 34F2 than the DS201579 strain (Figure 1). The DS201579 strain had also taken on a turbid appearance and the lysis zone began to spread a further $10 \mathrm{~mm}$ in diameter for the ensuing $4 \mathrm{~h}$. This indicated the presence of an infective agent such as a bacteriophage rather than the presence of an antimicrobial compound (which was also initially considered) in the filtrate. The viral filtrate concentration was determined to be $6.8 \times 10^{8} \mathrm{pfu} / \mathrm{mL}$ by plaque enumeration. For this reason, the B. anthracis isolate DS201579 was sub-cultured until such time as single colonies remained white and opaque, after plating, without developing plaques after $6 \mathrm{~h}$ at room temperature. This was to ensure that the isolates were "purified" of any latent bacteriophages.

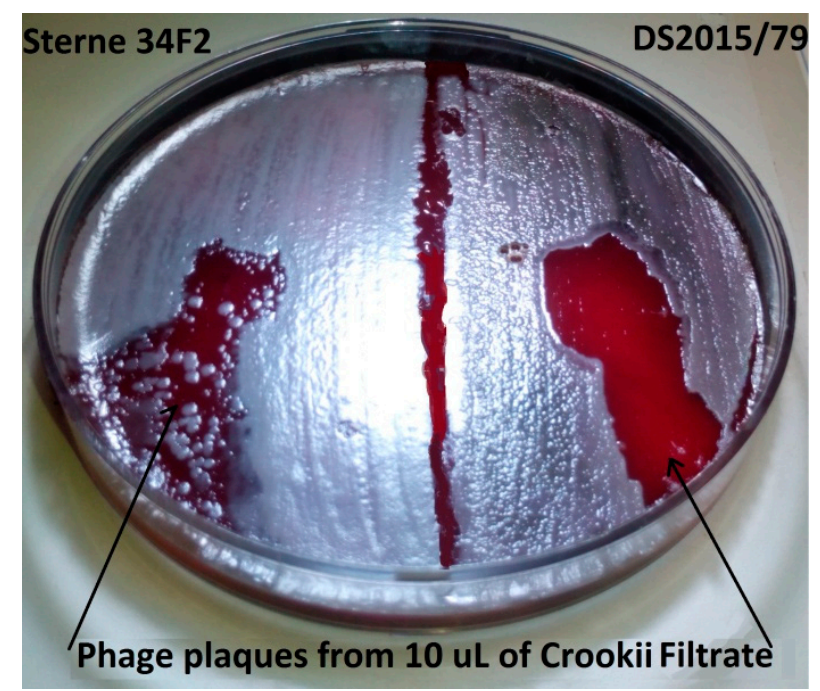

Figure 1. Blood agar plate with Bacillus anthracis bacterial lawns of Sterne 34F2 (left) and virulent DS201579 (right) after $12 \mathrm{~h}$ incubation at $37^{\circ} \mathrm{C}$. The plaques indicated by the arrows are where the bacteriophage Bacillus phage Crookii has lysed bacterial cells. The phage demonstrates a greater affinity for B. anthracis DS201579 than Sterne strain; where the DS201579 lawn is also displaying turbidity indicating phage infection.

Bacillus phage Crookii counts were stable up to $50^{\circ} \mathrm{C}$ for $15 \mathrm{~min}$ in Dulbecco's PBS buffer, however, there was no survivability after $60^{\circ} \mathrm{C}$ for $15 \mathrm{~min}$. This is why at least the $2 \mathrm{CFU}$ could be obtained from the heat treated swab; which allowed the spores to germinate and replicate. Subsequent serial passage (sub-culturing) of isolates appeared to "cure" the bacterium of the bacteriophage. The filtrate was also tested against bacterial lawns of B. cereus, B. thuringiensis, B. subtilis, and B. mycoides strains in order to determine its specificity. The phage was only lytic against B. anthracis, B. cereus, and B. thuringiensis, but demonstrated a greater affinity for encapsulated B. anthracis strains. Bacillus cereus only demonstrated plaques at very high viral concentrations $\left(>10^{9} \mathrm{pfu}\right)$, while $B$. thuringiensis revealed clear plaques only at the highest concentrations $\left(>10^{11} \mathrm{pfu}\right)$ 


\subsection{Transmission Electron Micrograph}

The identification of the bacteriophage was based on viral morphology fitting within the criteria for Myoviridae viruses (Figure S1): icosahedral head 60-145 nm; elongated heads $80 \times 110 \mathrm{~nm}$ and tail 16-20 × 80-455 $\mathrm{nm}$ according to Ackermann, (2011).

\subsection{The Effect of Viral Propagation on B. anthracis DS201579}

In order to determine the activity and effect of Bacillus phage Crookii on the bacterium at the carcass site, the virus was propagated under different conditions including sodium bicarbonate which is a natural trigger for encapsulation $[35,49]$. The mean spore counts were directly tabulated from 100 microscopic fields of Romanowsky-Giemsa stained smears taken at $8 \mathrm{~h}$ (to allow for spore germination and thereafter replication), $12 \mathrm{~h}$, and $24 \mathrm{~h}$ (Table S1). As indicated the blood smear analyses were to determine whether sporulation triggered a defense mechanism against phage infection or whether it is a response to nutrient availability. A graphical representation of the different conditions can be seen in Figure 2 where typical microscopic fields were visualized for cell enumeration. Appendix A includes a descriptive analysis of the interaction between the bacteriophage, host bacterium, and nutrient availability in the environment. The blood smears revealed that encapsulated B. anthracis strain DS201579 fared much better than unencapsulated Sterne strain in the changing blood conditions (Table S1, Figure A1, Figure A2A-C). This could be seen at $12 \mathrm{~h}$ counts where all the Sterne strain cells had sporulated, while the DS201579 strain still had replicating vegetative cells. The presence of the bacteriophages also resulted in lower end point bacterial counts for both bacterial strains (Table S1, Figure A3A-D). Sterne strain was similarly affected by both Bacillus phage Crookii and $\gamma$-phage. Despite strain DS201579 demonstrating a better replication efficiency, the presence of Bacillus phage Crookii resulted in lower end point counts than Sterne vaccine strain (Table S1, Figure A4A-D). For both bacteria sporulation was triggered earlier during the logarithmic phase in the presence of bicarbonate, carbon dioxide, as well as the presence of a lytic bacteriophage (Table S1, Figure A5A-E, Figure A6A-E, Figure A7A-F).

\subsection{Genomic Features of Bacillus Anthracis DS201579}

About 140X sequenced coverage of the trimmed reads were used to assemble the 32 contigs of B. anthracis DS201579 genome (Table S2). The genome features of B. anthracis DS201579 presented a chromosome of 26 contigs, two plasmids pX01 of four contigs and pX02 assembled as one contig (Table S2). The genome coverage of B. anthracis DS201579 (5.45Mb) was about $99 \%$ with respect to $B$. anthracis Ames ancestor $(5.50 \mathrm{Mb})$. An average $\mathrm{G}+\mathrm{C}$ content of $35 \%$ was determined in the B. anthracis DS201579. Annotation of the bacterial genome using NCBI Prokaryotic Genome Annotation Pipeline presented 5724 coding sequences (CDSs) with a total of 94 RNA genes. Five prophages were determined in the chromosome of B. anthracis DS201579. The prophages nucleotide sequences were not $100 \%$ identical with the query or given sequences in GenBank. This included the LambdaBa01, LambdaBa02, LambdaBa03, LambdaBa04 and a partial prophage referred to in general terms as Phage_Bacilli pfEDR_5_NC_031055 (Table S3).

Read mapping analysis of B. anthracis DS201579 determined that it consists of chromosomes, pX01 and pX02. Analysis of the unmapped reads of the DS201579 strain from the read mapping analysis resulted in eight contigs with less than $400 \mathrm{bp}$ size and low sequence coverage on the contigs (Table S4). The eight contigs had a BLASTn homolog to partial/minor phages with no resemblance to either of the bacterial prophages nor Bacillus phage Crookii. They had similar sequence identities of $\leq 90 \%$ with Bacillus phage WPh. Neither of these identified contigs are similar when aligned to Bacillus phage Crookii. This is indicative of multiple possible phage infection events of B. anthracis strain DS201579 by Myoviridae environmental phages over time. 
(a)

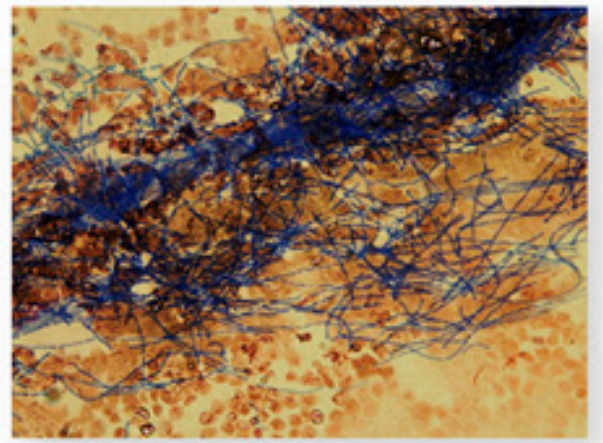

(c)

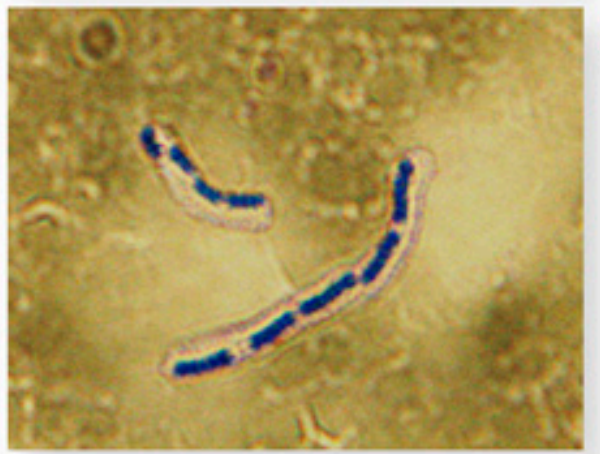

(e)

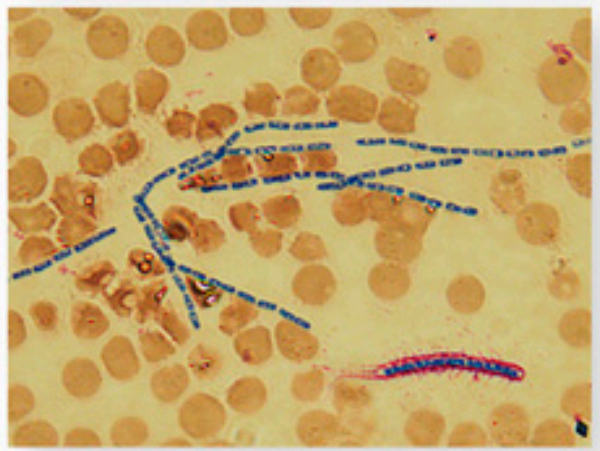

(g)

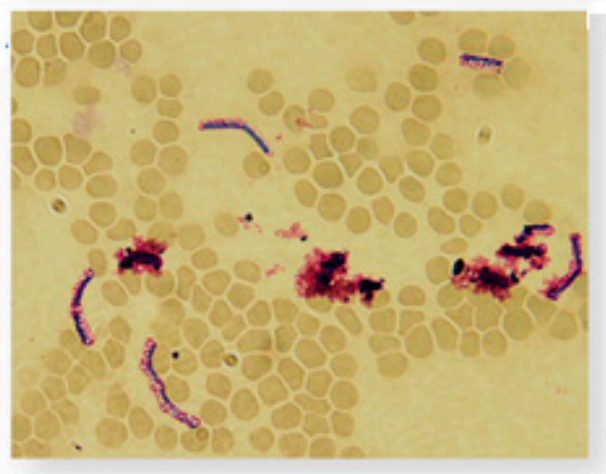

(b)

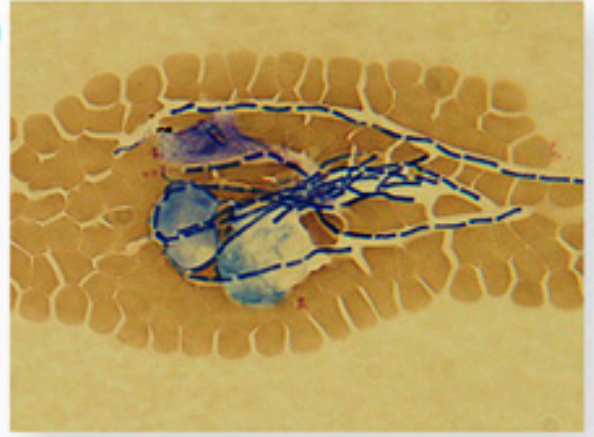

(d)

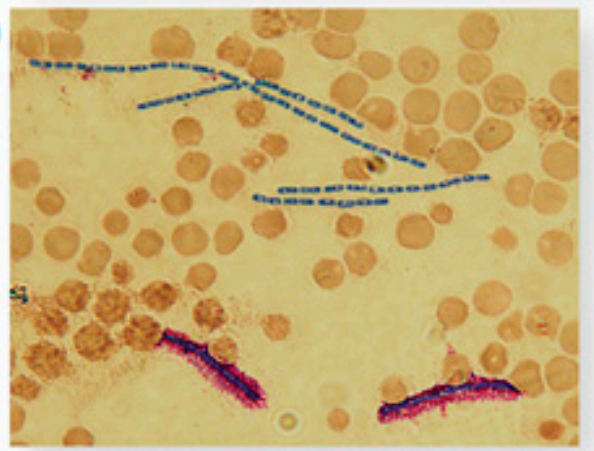

(f)

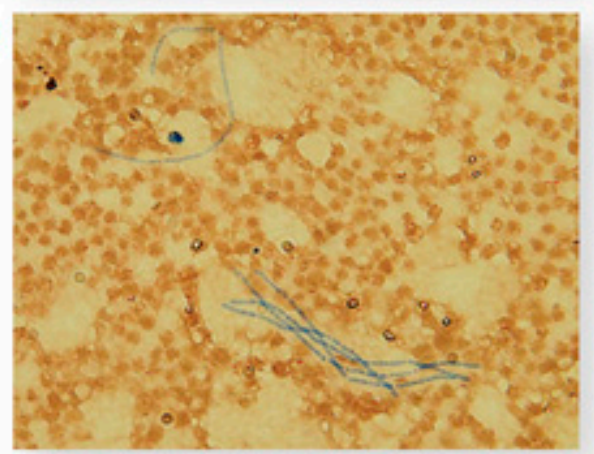

(h)

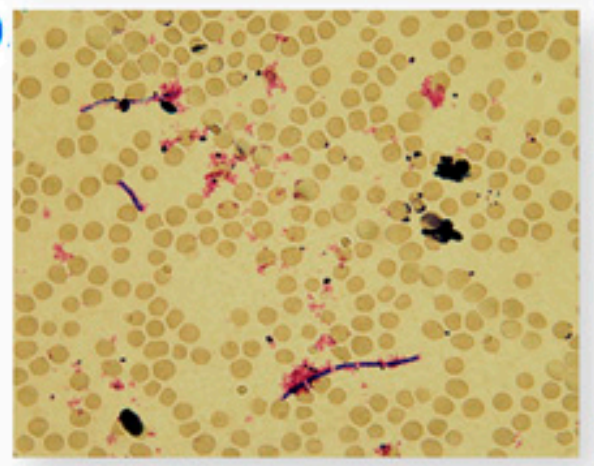

Figure 2. Romanowski-Giemsa-stained blood smears of Bacillus anthracis at 1000x magnification. (a) Unencapsulated B. anthracis Sterne vaccine strain at $12 \mathrm{~h}$ of $37^{\circ} \mathrm{C}$ incubation. (b) Sterne with $\gamma$-phage at $8 \mathrm{~h}$ of $37^{\circ} \mathrm{C}$ incubation. (c) B. anthracis DS201579 showing encapsulation (balloon-like layer) at $8 \mathrm{~h}$ of $37^{\circ} \mathrm{C}$ incubation. (d) DS201579 with $\mathrm{NaHCO}_{3}$ in $8 \% \mathrm{CO}_{2}$ at $8 \mathrm{~h}$ of $37^{\circ} \mathrm{C}$ incubation showing thickened capsule (purple) and cells with endospores (blue). (e) DS201579 at $37^{\circ} \mathrm{C}$ incubation for $12 \mathrm{~h}$ in $8 \% \mathrm{CO}_{2}$ where all cells contain endospores (blue) and degradation of mother cell has begun (purple streaks). (f) DS201579 with $\mathrm{NaHCO}_{3}$ and $8 \% \mathrm{CO}_{2}$ at $37^{\circ} \mathrm{C}$ incubation for $12 \mathrm{~h}$ of showing $100 \%$ sporulation. (g) DS201579 with Bacillus phage Crookii at $37^{\circ} \mathrm{C}$ incubation for $12 \mathrm{~h}$ and $8 \% \mathrm{CO}_{2}$ of showing lysed cells as well as intact endospores. (h) DS201579 with Bacillus phage Crookii at $37^{\circ} \mathrm{C}$ incubation for $12 \mathrm{~h}$ where all vegetative cells in view were lysed. 
Genomic Features of Bacillus Phage Crookii

De novo assembly of the Bacillus phage Crookii resulted in a single contig with 70X sequence coverage. The bacteriophage identified as Bacillus phage Crookii is a dsDNA Myoviridae virus $\sim 154,012$ bp with a $\mathrm{G}+\mathrm{C}$ content of $37 \%$. The number of coding sequences identified by RAST for this phage was 235. About $94 \%$ of the annotated CDS's are hypothetical while $6 \%$ have a known protein nomenclature. This included the lysins, head/capsid proteins, cell wall binding proteins, base plate proteins, replication, and packaging machinery (Table S5). No intergrase/recombinase proteins were determined in the Bacillus phage Crookii, confirming it to be lytic in behavior. The genome properties of Bacillus phage Crookii codes for lysine $N$-acetyl-muramoyl-L-alanine amidase (endolysin), which is responsible for bacterial lysis. It contained multiple tRNA genes namely, tRNA-Asn-GTT (asparagine) and tRNA-Asp-GTC (aspartate). It also had coding regions for the metal-dependent hydrolases of the metallobeta-lactamase superfamily and RNA polymerase sigma factor SigB (Table S1).

BLASTn comparison of Bacillus phage Crookii on NCBI revealed a viral strain relationship to a Myoviridae Bacillus phage WPh., isolated from an anthrax positive zebra carcass in Namibia [50,51]. The whole genome of Bacillus phage Crookii was compared and aligned with Bacillus phage WPh. (Figure S2). The genome size of Bacillus phage WPh. is 156,897 bp. Bacillus phage Crookii demonstrated $83 \%$ query cover and 85\% sequence identity with WPh accession number HM144387.1. The G+C content of Bacillus phage WPh phage is $36.4 \%$, which compares well with Bacillus phage Crookii. The same number of tRNA's were observed on the genomes of both phages. Phylogenetic analysis of Bacillus phage Crookii showed that it groups with other related B. cereus-group phages (Figure 3). Bacillus phage Crookii also groups closely in the same cluster with Bacillus phage WPh.

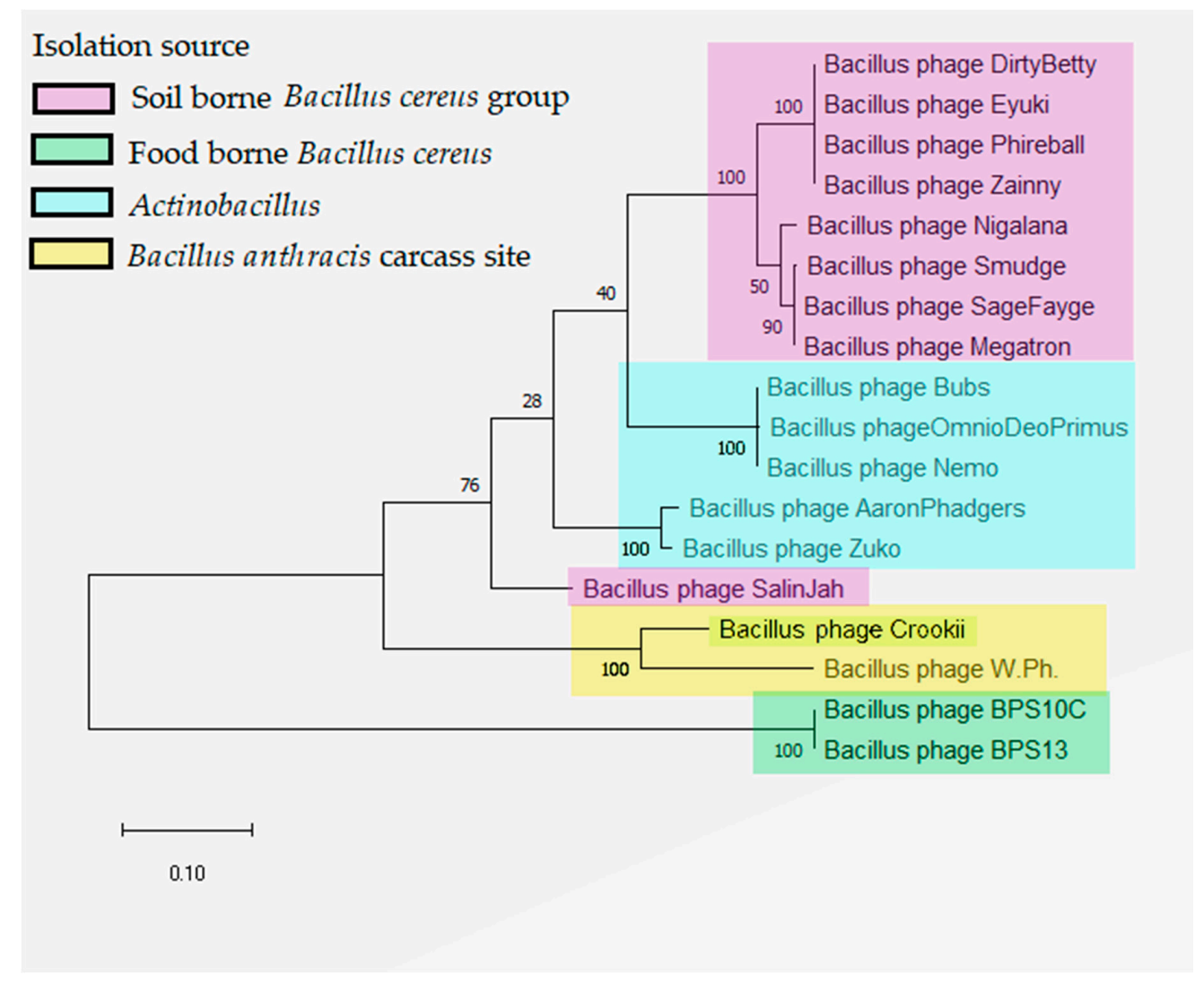

Figure 3. Maximum likelihood phylogeny for the Bacillus phages based on the phage major capsid protein showing the clustering of Bacillus phage Crookii (highlighted in yellow along with anthrax associated Bacillus phage WPh). Bootstrap values $>28 \%$ are indicated at the internodes. Bacteriophages infecting Bacillus spp. cluster according to their isolation source (indicated in the color legend). 


\section{Discussion}

This study is the description of the unique isolation of a lytic bacteriophage, Bacillus phage Crookii infected B. anthracis DS201579 strain from a wildebeest carcass in Pafuri close to Crooks corner in KNP. In the diagnostic evaluation of the carcass site DS201579, the apparent "sterility" of the untreated blood agar plates drew special attention to the samples from this site. The novelty of the identification of Bacillus phage Crookii and its inherent appetite for B. cereus, B. thuringiensis and B. anthracis in culture is what sets this bacteriophage isolation apart. The heat-treated samples from the carcass site yielded B. anthracis spores, but only two small colonies on enrichment medium from a biological sample is unusual. When sub-cultured, plaques once again appeared over time, indicating that even these spores failed to escape infection. The inability to obtain isolates from the swab before the heat treatment indicates that the bacteriophage was active in the sample.

Bacteriophages are not able to infect bacterial spores [52], but they are able to harbor within spores after infection of a vegetative cell $[53,54]$. The bacteriophage infected bacteria are also able to persist in biofilms, created by bacteria, in the environment $[18,55]$. The tailed phages, of which Myoviridae phages form a part, tend to be the most resilient, abundant, and stable to environmental factors [22,56]. This does not mean that these phages will survive for prolonged periods outside of their ideal conditions. Phages are certainly sensitive to external environmental factors such as temperature and $\mathrm{pH}$ ranges [56,57]. This highlights why multiple bacterial hosts would be required to subsist between anthrax outbreaks in the environment. That said; Bacillus phage Crookii demonstrated a much greater affinity for encapsulated B. anthracis strains from the anthrax endemic region of Pafuri, however, it could also infect unencapsulated B. anthracis Sterne and B. cereus, but only at much higher viral concentrations. Under such conditions, it can be said that, at low concentrations of Bacillus phage Crookii there is a higher specificity for pathogenic B. anthracis in the anthrax enzootic region of Pafuri. The wider host range for other $B$. cereus-group members may just be due to a similarity in receptor sites and in the wider context as a phage survival mechanism.

To explore factors that influence bacteriophage infection of the bacterium, we simulated decomposing carcass conditions. The spores from un-encapsulated B. anthracis Sterne versus the encapsulated B. anthracis DS201579 strains were incubated under different conditions of oxygen concentration, $\mathrm{pH}$ and bicarbonate content as a control for comparison of the phage effects. The inclusion of $8 \% \mathrm{CO}_{2} /$ bicarbonate was to stimulate thickening of the pathogenic B. anthracis capsule $[49,58]$ and to mimic carcass blood conditions [59]. The germination of the spores was lower in the presence of sodium bicarbonate, under standard incubation conditions, and even lower when combined with $8 \%$ $\mathrm{CO}_{2}$. This is expected because of the inhibitory nature of the combination of $\mathrm{CO}_{2}$ [60] and sodium bicarbonate [61] in the germination of soil-borne spore formers. Since bacteriophages cannot infect bacterial spores [52,54]; sporulation before infection by the phage would ensure the bacterium's persistence in the environment. The blood smear analyses were aimed at visually appraising whether sporulation is triggered as a defense mechanism against phage infection [26,34] or in response to nutrient availability [35] through cell enumeration. From the results, sporulation is in response to nutrient availability as well as in response to the presence of a lytic bacteriophage. This demonstrates the complexity of factors which affect the survival and persistence of inoculum in the environment.

Bacillus phage Crookii proved more lytic than Gamma $(\gamma)$-phage to DS201579 based on plaque zones at the same bacteriophage concentration. There seemed to be no difference in the effect between Crookii and Gamma on the un-encapsulated Sterne strain. Bacillus anthracis DS201579 did not appear to develop any phage resistance characteristics over time, escaping lysis only through sporulation. Sporulation and replication activity were due to nutrient availability. The presence of bacteriophages also resulted in early onset sporulation. It has been suggested that this could be a bacterial survival mechanism against bacteriophage infection [34]. The presence of the sodium bicarbonate and the carbon dioxide inhibited spore germination irrespective of the presence of the phages and therefore resulted in higher end point spore counts due to the inability of the phages to infect the bacteria. The lower bacterial counts from samples which included bacteriophages demonstrates the aggressive 
ability of environmental phages like Bacillus phage Crookii to reduce overall bacterial counts at the endpoint. This is due to the fewer vegetative cells available for replication during the 0 to $12 \mathrm{~h}$ logarithmic incubation period and its coinciding with the highest infectivity period of the phage [25,62]. This suggests a more opportunistic infection ability of the bacteriophage.

The smears were also used to evaluate whether the bacteriophages would lyse all available vegetative cells under optimum conditions of bacterial replication. It appears as though the sporulated bacteria have escaped infection, but when these spores are plated out, phage plaques once again become apparent. It has been suggested that bacteriophages are able to "read" the quorum signals of their hosts and are therefore likely to halt further bacterial lysis at the peak of host death [63]. The bacteriophages can then remain dormant within the host until germination and replication is triggered. Since spores are far more stable and resilient to environmental conditions, this allows persistence of the bacteriophage within the soil environment and host population.

While the lytic effects of the bacteriophage on $B$. anthracis are quite apparent, a genetic analysis of the bacterium and virus highlighted an alternative relationship as well. The genome of Bacillus phage Crookii included a potential coding region for the metal-dependent hydrolases of the metallobeta-lactamase superfamily, which was previously described in $B$. cereus for conferring resistance to carbapenems $[64,65]$ to prevent premature lysis of the bacterial cell by external factors [56]. No holin coding region was observed in this genome; however, a large number of hypothetical proteins in the genome were specified to still require annotation. Comparative sequence analysis identified a close relative to Bacillus phage Crookii in the form of Bacillus phage WPh. Bacillus phage WPh. was isolated from an anthrax positive zebra carcass in Etosha National Park, Namibia [50,51]. Both phages are Myoviridae dsDNA bacteriophages based on similar GC content and sequence identity with characteristics of Spounaviruses [51,66]. These bacteriophages infect members of the B. cereus sensu lato group. It can be seen that the relationship between these two bacteriophages, which are associated with anthrax carcass sites on opposite sides of the African continent, are much closer than those isolated from B. cereus, B. thuringiensis and other Bacillus spp (Figure 3).

Bacillus anthracis DS201579 genome features consists of the chromosomes, pX01 and pX02. The prophages determined in this study were also reported to be present in B. anthracis Ames ancestor [67]. Different sizes of the prophage regions were also observed in the genome of B. anthracis DS201579. PHASTER analysis of the bacterial genome revealed only the four prophage regions that have been well described for B. anthracis $[9,14,68]$ as well as, a previously characterized partial prophage [14,69]. A separate partial phage was also identified in the analysis of the unmapped reads of the bacterial genome. This phage had similarities with Bacillus phage WPh., but the contigs did not align with Bacillus phage Crookii. This is an indication of past infection events of the bacterium. Phage infection by virions already present in the bacterium can confer phage resistance to infection by new bacteriophages as well as through origin-derived phage-encoded resistance [70,71], however, this was not the case for B. anthracis DS201579 and Bacillus phage Crookii.

\section{Conclusions}

Bacillus phage Crookii is an aggressively lytic dsDNA Myoviridae bacteriophage infecting B. anthracis in the environment of Pafuri, KNP. The phage presented itself as an unusual isolate during diagnostics from a carcass in an anthrax outbreak. Since no bacteria could be isolated from soil and only heat treatment greater than $60^{\circ} \mathrm{C}$ yielded B. anthracis from a blood swab, it demonstrates the role of environmental bacteriophages in the natural reduction of bacterial inoculum at carcass sites.

Whole genome sequencing of $B$. anthracis DS201579 revealed the presence of the lambdaBA phages that have been previously described in Ames ancestor and commonly found among B. anthracis. No bacteriophages, other than the expected four (Lambda BA01, BA02, BA03, and BA04) and Phage_Bacilli_pfEDR_5, were identified within the host bacterial genome as determined by whole genome sequencing. 
The remnants of another partial phage within the B. anthracis DS201579 strain is suggestive of multiple possible phage infection events of the B. anthracis strain (DS201579) by Myoviridae environmental phages over time. Despite this, B. anthracis DS201579 did not manifest phage resistance characteristics against Bacillus phage Crookii even after serial passage. The initial isolation of the bacterium highlighted the bacteriophages ability to harbor within spores, thus persisting alongside the bacterium until germination.

Bacillus phage Crookii demonstrated a viral strain sequence identity relationship to Bacillus phage WPh. The sequence similarity of these hypervariable environmental Myoviridae bacteriophages is descriptive of the common ecology within African soil biomes despite geographical disparity.

The identification of Bacillus phage Crookii was fortuitous but was indicative of how many phages must be missed during routine bacterial diagnostics. Recent studies have shown that the isolation methods popularly employed in the isolation of bacteriophages from water and soil biomes (including this study) select against larger, more complex bacteriophages [72]. Bacillus phage Crookii and other lytic bacteriophages represent an efficient pathogen bioremediation mechanism in the environment. They could prove to be the missing link in determining outbreak termination in endemic/enzootic regions. More study is required for understanding the complexity of soil-borne factors influencing anthrax outbreaks.

Supplementary Materials: The following are available online at http://www.mdpi.com/2076-2607/8/6/932/s1, Table S1. To determine the Bacillus phage Crookii effects on Bacillus anthracis in decomposing blood, Romanowsky-Giemsa stained smears were visually appraised microscopically at three time points. The bacterial counts (vegetative cells versus endospores) were enumerated under different conditions (standard incubation, carbon dioxide incubation, sodium bicarbonate content and bacteriophage type) for comparison. Counts represent cells/spores per $100 \mu \mathrm{L}$ of blood. Table S2. General features of the genome sequence of Bacillus anthracis DS201579 and Bacillus phage Crookii. Table S3. Five prophages of Bacillus anthracis DS201579 in the chromosome identified using PHASTER. Table S4. De novo assembly of unmapped reads collected from read mapping analysis of Bacillus anthracis DS201579 using B. anthracis Ames Ancestor as a reference genome (GenBank accession: NC_007530.2; NC_007322.2 and NC_007323,2). Table S5: RAST annotation of contig sequences of the Bacillus phage Crookii genome. Figure S1. Transmission electron micrographs of bacteriophage Bacillus phage Crookii, isolated from an anthrax carcass site in Kruger National Park, South Africa. It was negatively stained with $2 \%$ uranyl acetate. Bacillus phage Crookii has a Myoviridae morphology with a thickened contractile tail in relation to the head. The head is $\sim 80 \mathrm{~nm}$ with a tail measuring $\sim 205 \mathrm{~nm}$. Figure S2. The CGView comparative tool map of Bacillus phage Crookii genome sequence to Bacillus phage WPh. Circles display from inside to outside: genomic position in kilobases, GC skew (purple and green), GC content (black). Blast 1 results show the sequence homolog between Bacillus phage Crookii and phage WPh (blast 2). Open reading frames are indicated as pink from the outside.

Author Contributions: Conceptualization, A.H. and H.v.H.; methodology, A.H., E.H.D., and K.E.L.; software, K.E.L.; formal analysis, A.H. and K.E.L.; investigation, field sampling and disease identification A.H., E.H.D. and D.S.v.D.; resources, H.H.; data curation, A.H. and K.E.L.; writing-original draft preparation, A.H.; writing-review and editing, H.H.; visualization, A.H. and K.E.L.; project administration, H.H.; funding acquisition, H.v.H. All authors have read and agreed to the published version of the manuscript. Authorship must be limited to those who have contributed substantially to the work reported.

Funding: It was obtained from the National Research Foundation (NRF) grant 78909 and AgriSETA (Agriculture Sector Education Training Authority) of South Africa. Department of Agriculture Fisheries and Forestry (DAFF) approval 12/11/1/1/6 according to Section 20 of the Animal Disease Act 1984 (Act 35 of 1984), South Africa. University of Pretoria, Faculty of Veterinary Science Research VO67-12 and Animal S4285-15 ethics approvals. Ethics and project approval was also obtained from SANparks Scientific Services VHEH789.

Acknowledgments: The veterinarians and staff of Skukuza State Veterinary Services and the South African National Parks, Kruger National Park. Sunday Ochai for his help with R statistical analysis. Courtney Coon for her help with spore counts on the stained smears and Wolfgang Beyer for his mentorship.

Conflicts of Interest: The authors declare no conflict of interest.

\section{Appendix A}

Data Visualization of phage-bacterium-environment interactions (based on Table S1)

Generated in: R Core Team (2014). R: A language and environment for statistical computing. 
Figure A1: Average change in spores and cell counts do not seem to inherently differ between the two bacteria types namely encapsulates Bacillus anthracis 201579 and un-encapsulates B. anthracis 34F2 Sterne strain.

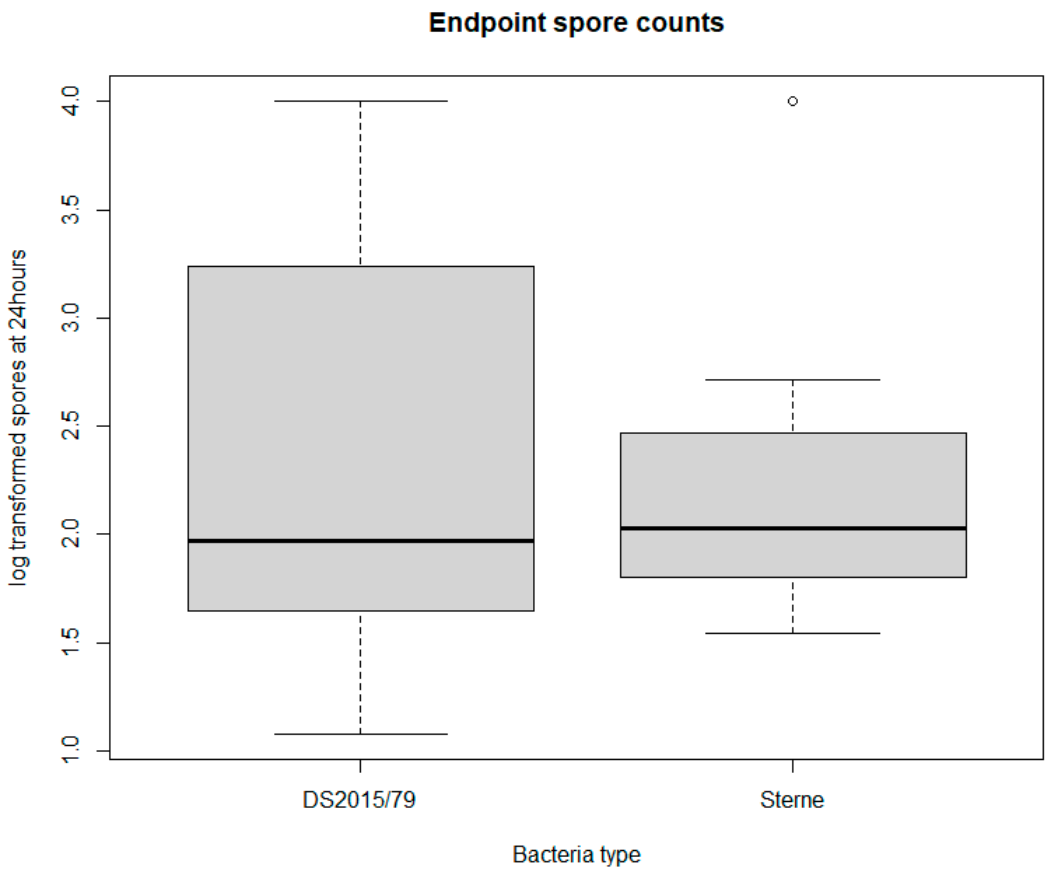

Figure A1. Median and box plots of endpoint spore counts between Bacillus anthracis strains DS201579 and Sterne vaccine strain.

Figure A2A-C: Cell and spore, counts differ between the two bacteria types. There is far more variation in B. anthracis DS201579 cell counts than Sterne. The median of the two bacteria remain comparable never-the-less.

A

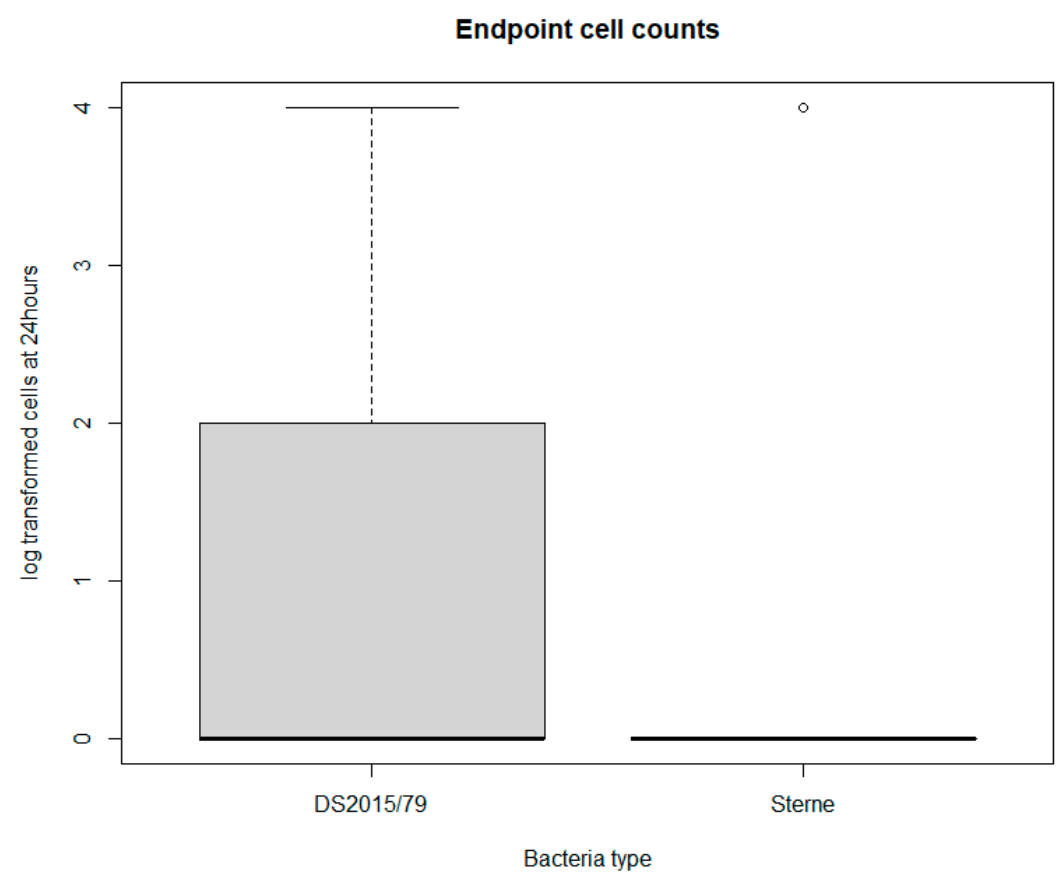

Figure A2. Cont. 
B

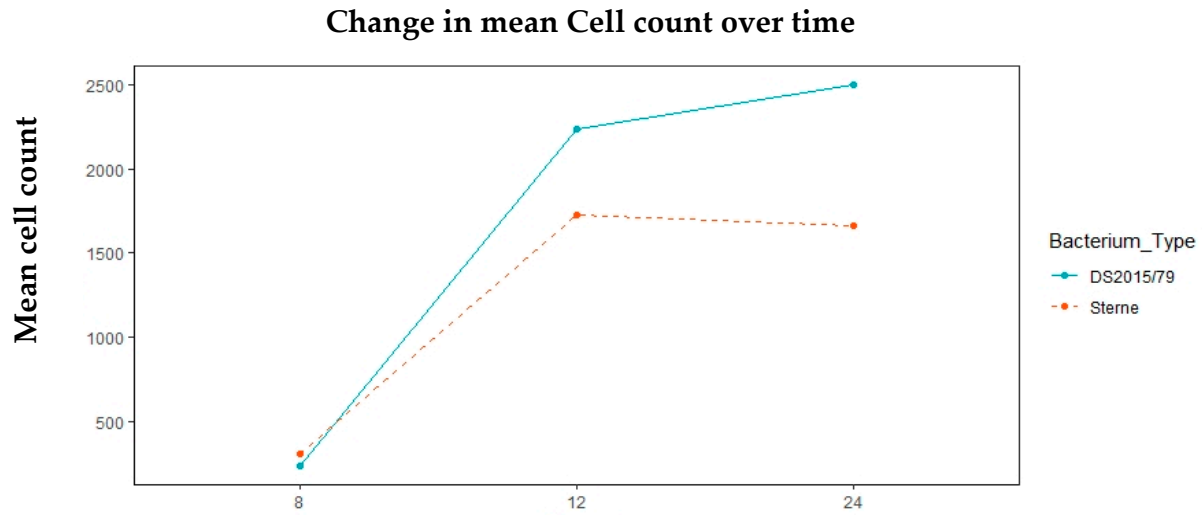

Time in hours

C

Change in mean spore count

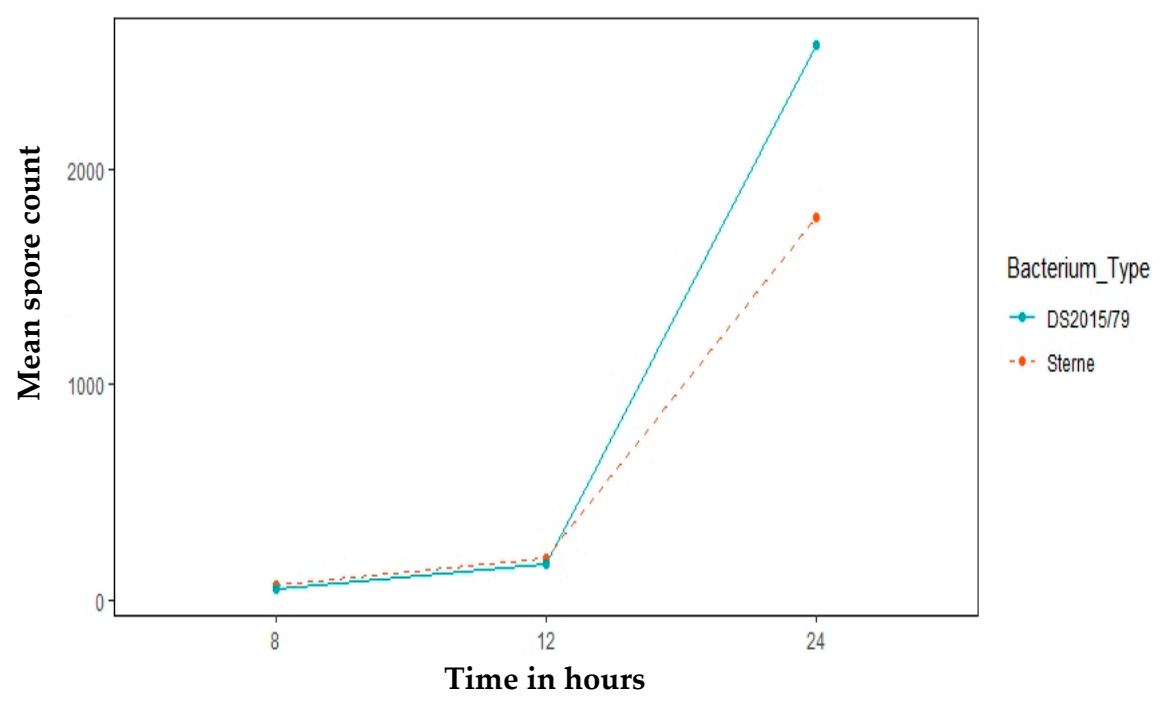

Figure A2. (A): Median of endpoint cell counts between Bacillus anthracis strains DS201579 and Sterne vaccine strain. (B): Mean cell counts between Bacillus anthracis strains DS201579 and Sterne vaccine strain. (C): Mean spore counts between Bacillus anthracis strains DS201579 and Sterne vaccine strain.

Figure A3A,B: Absence of phage equates to more cells and spores of Bacillus anthracis control strain Sterne 34F2 (because there is no predation). 
A

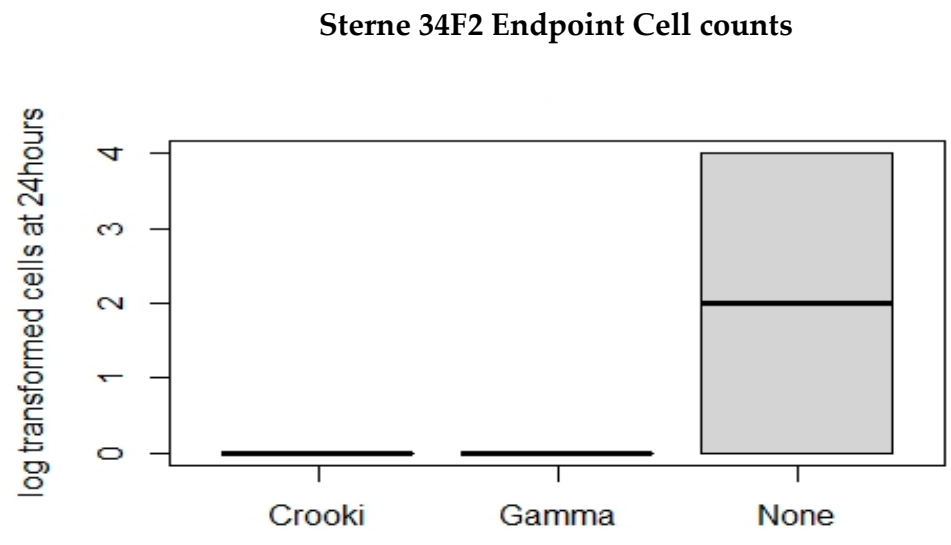

Bacteriophage type

B

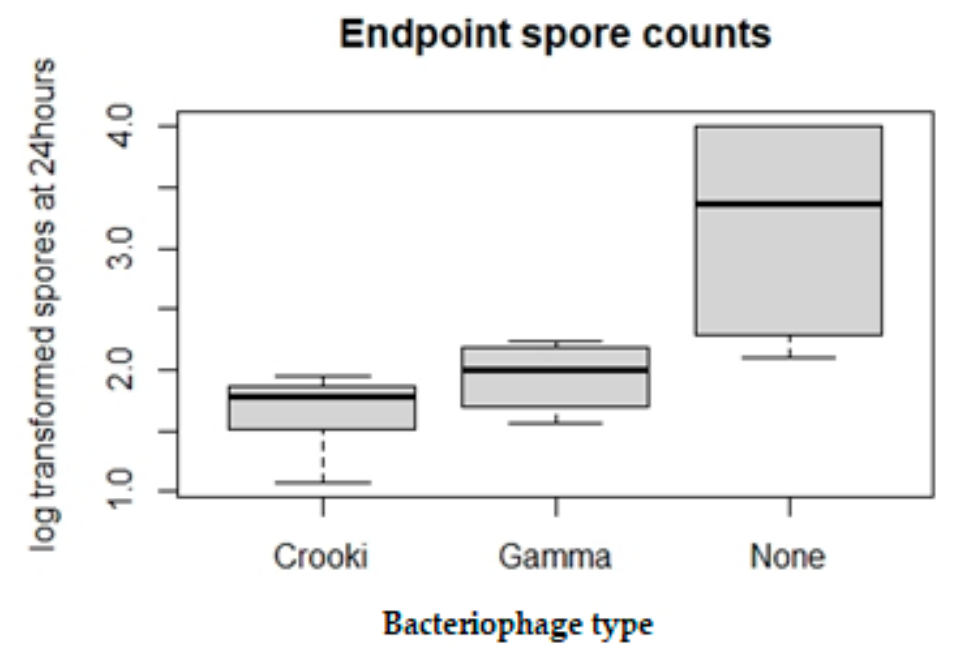

Figure A3. (A): Endpoint Sterne vaccine strain cell counts in the presence and absence of B. anthracis phages Crookii and Gamma. (B): Endpoint Bacillus anthracis spore counts when inoculated with B. anthracis phages.

Figure A4A-D: Absence of phages increases cells and spore counts regardless of bacterial strain (Bacillus anthracis DS201579 and Sterne 34F2) type. 
A

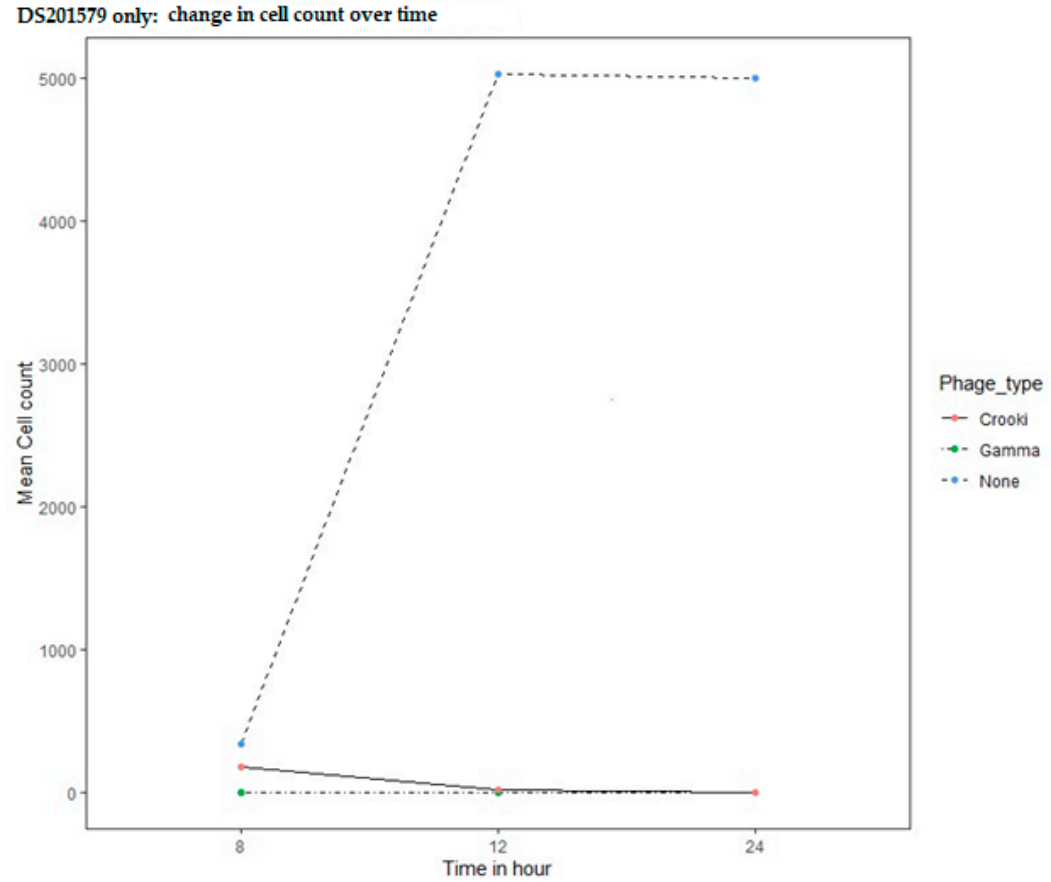

B

Sterne only: Change in cell count over time

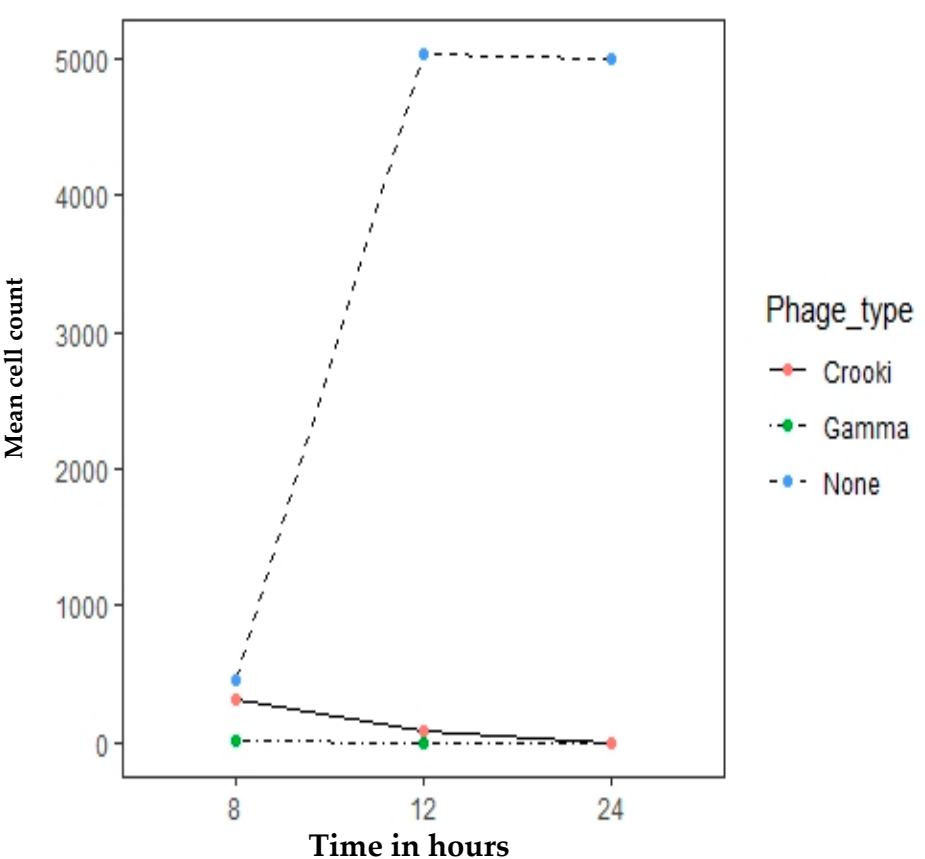

Figure A4. Cont. 
C

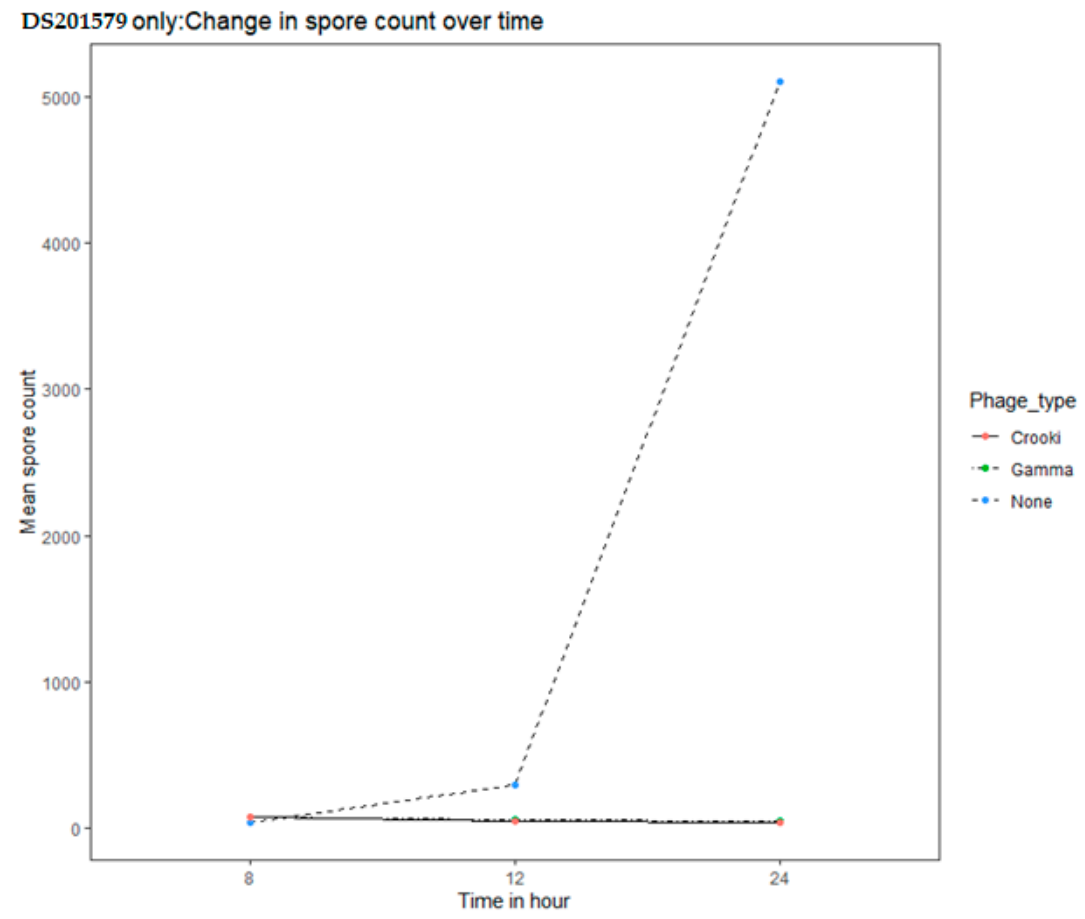

D

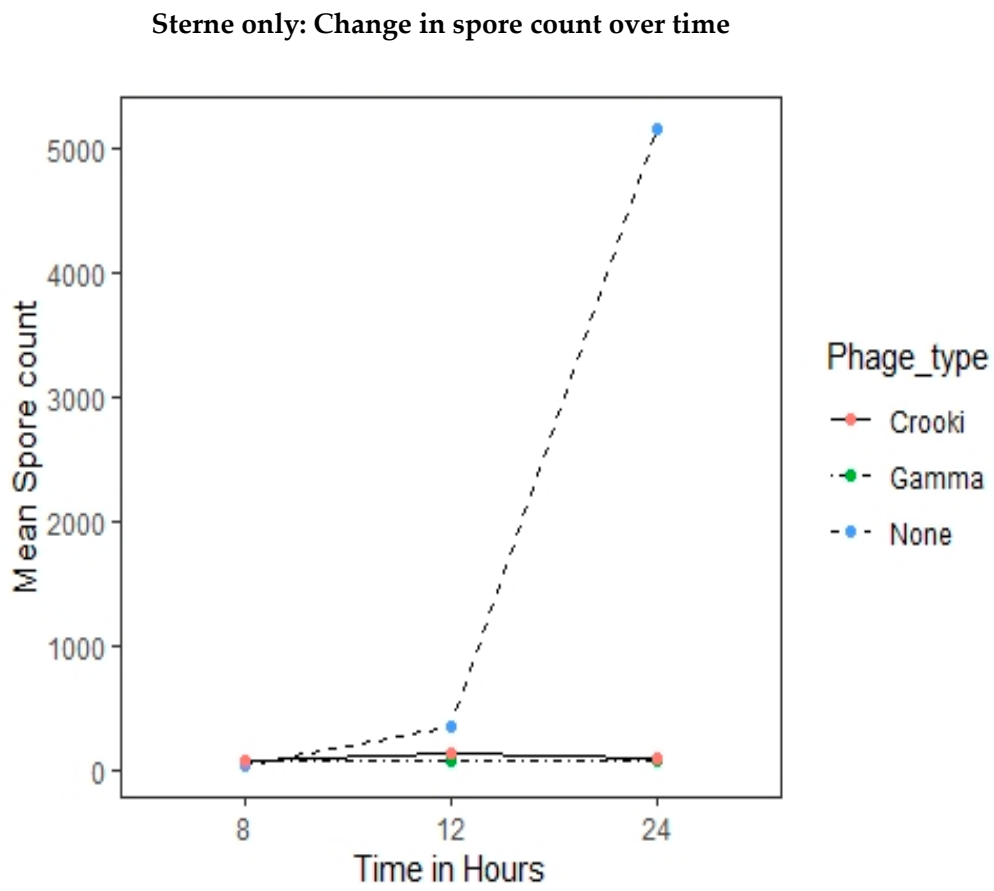

Figure A4. (A): Change in cell counts for Bacillus anthracis strain DS201579 under normal conditions and when inoculated with Gamma phage. (B): Change in cell counts for Bacillus anthracis Sterne strain under normal conditions and when inoculated with Gamma phage. (C): Change in spore counts for Bacillus anthracis strain DS201579 under normal conditions and when inoculated with Gamma phage. (D): Change in cell counts for Bacillus anthracis Sterne strain under normal conditions and when inoculated with Gamma phage. 
Figure A5A-E: There does not appear to be an effect of incubation type. However, there is a difference between the bacterial types (same pattern but note the differences in scale for Bacillus anthracis DS201579 and Sterne 34F2).

A

Sterne only: Change in cell count over time

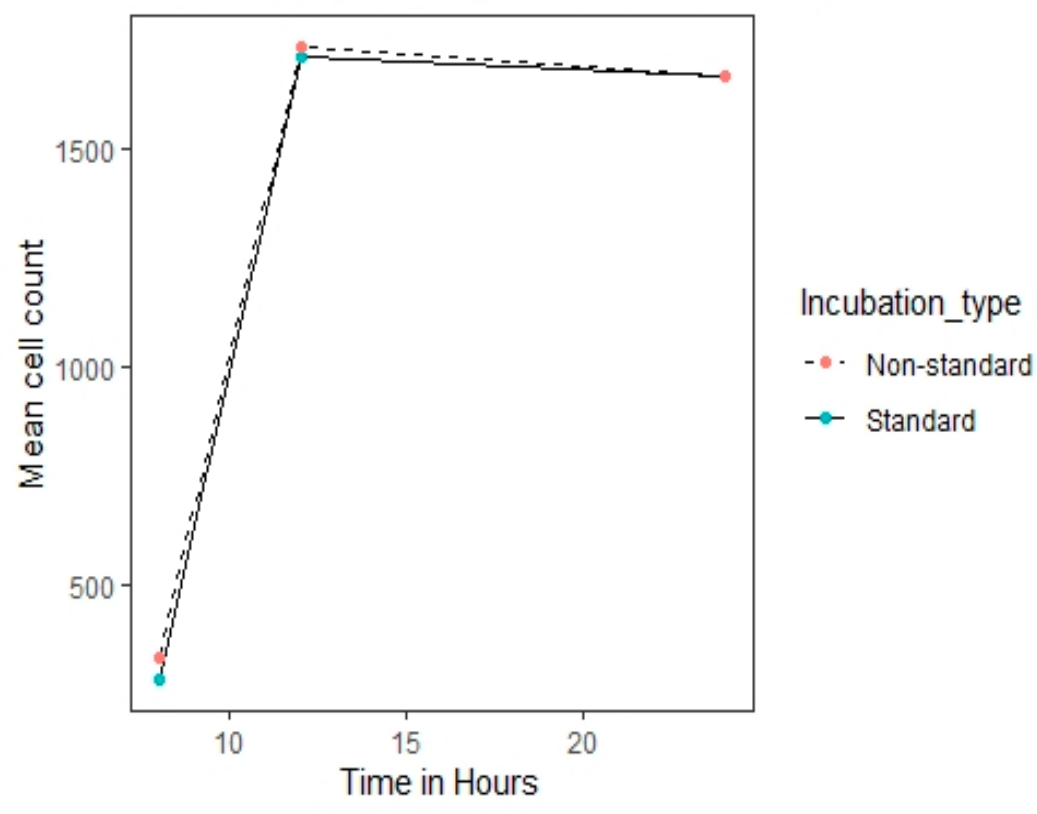

B

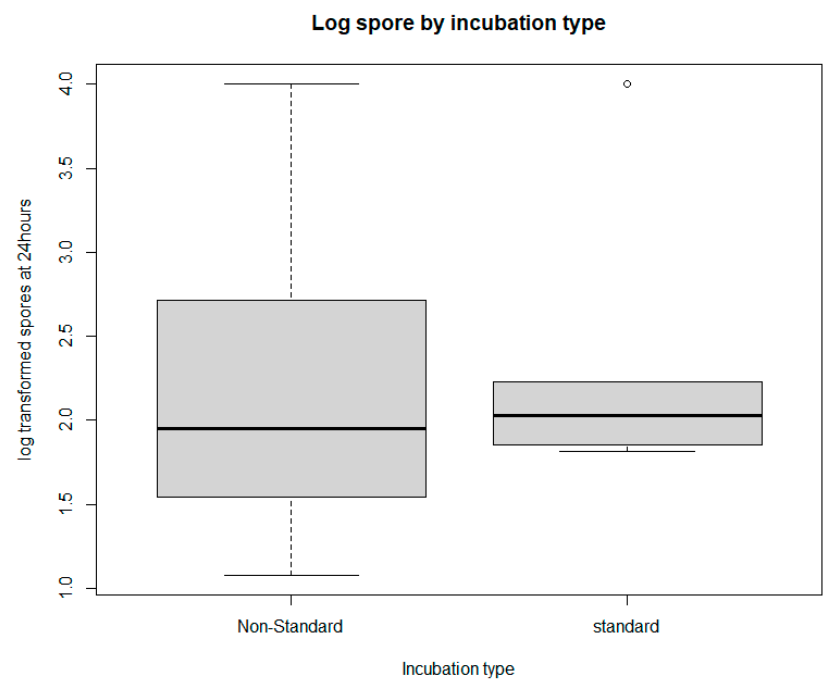

Figure A5. Cont. 
C

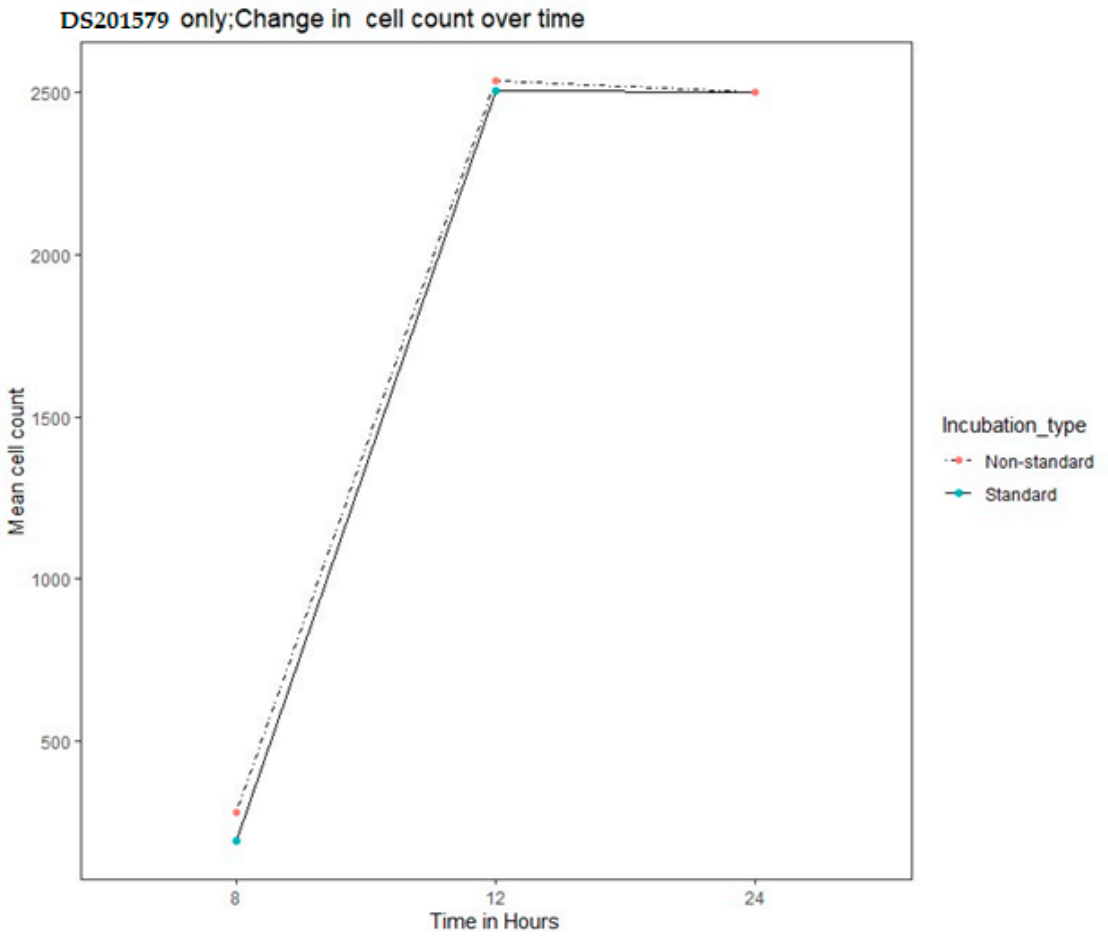

D

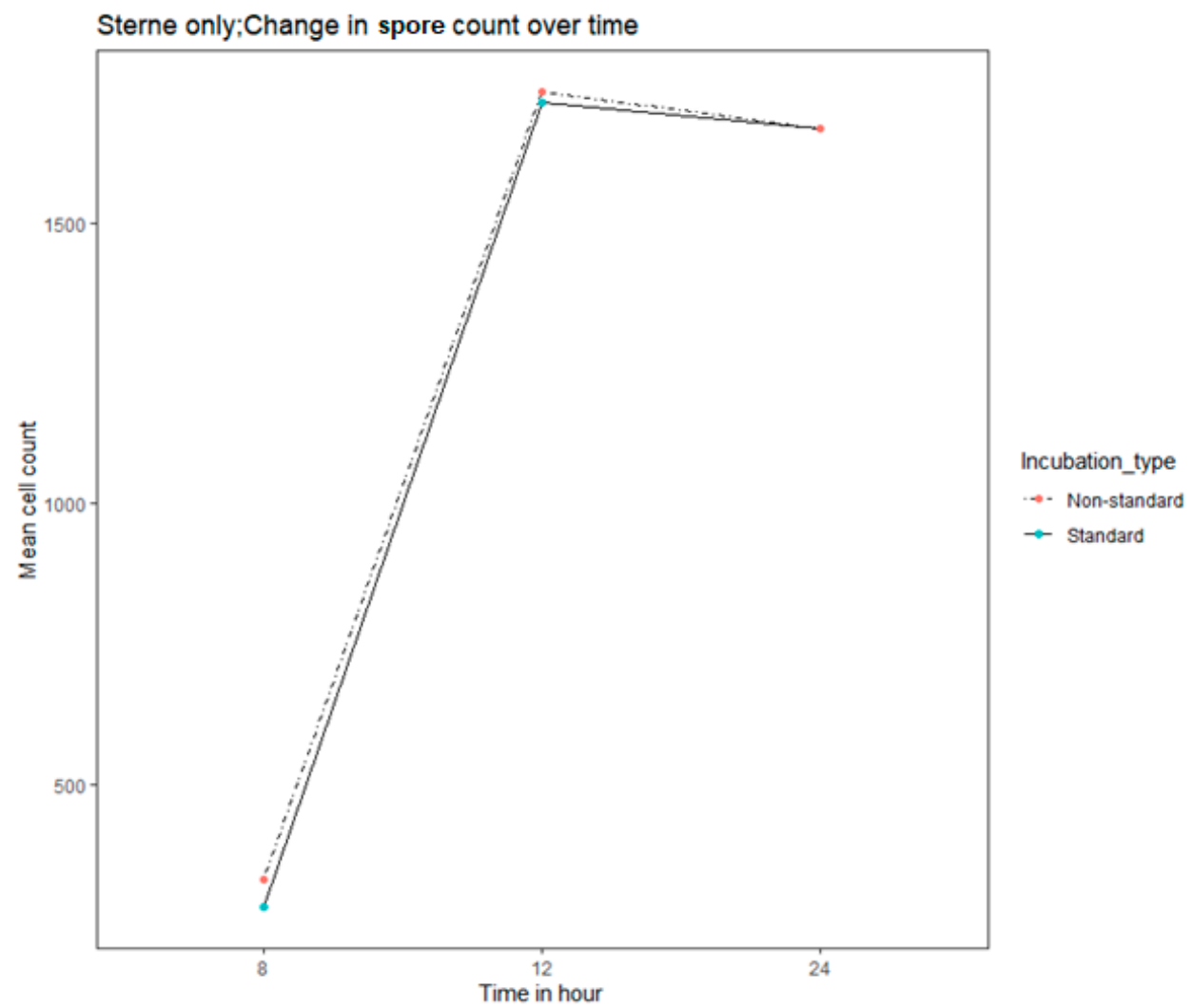

Figure A5. Cont. 


\section{$\mathbf{E}$}

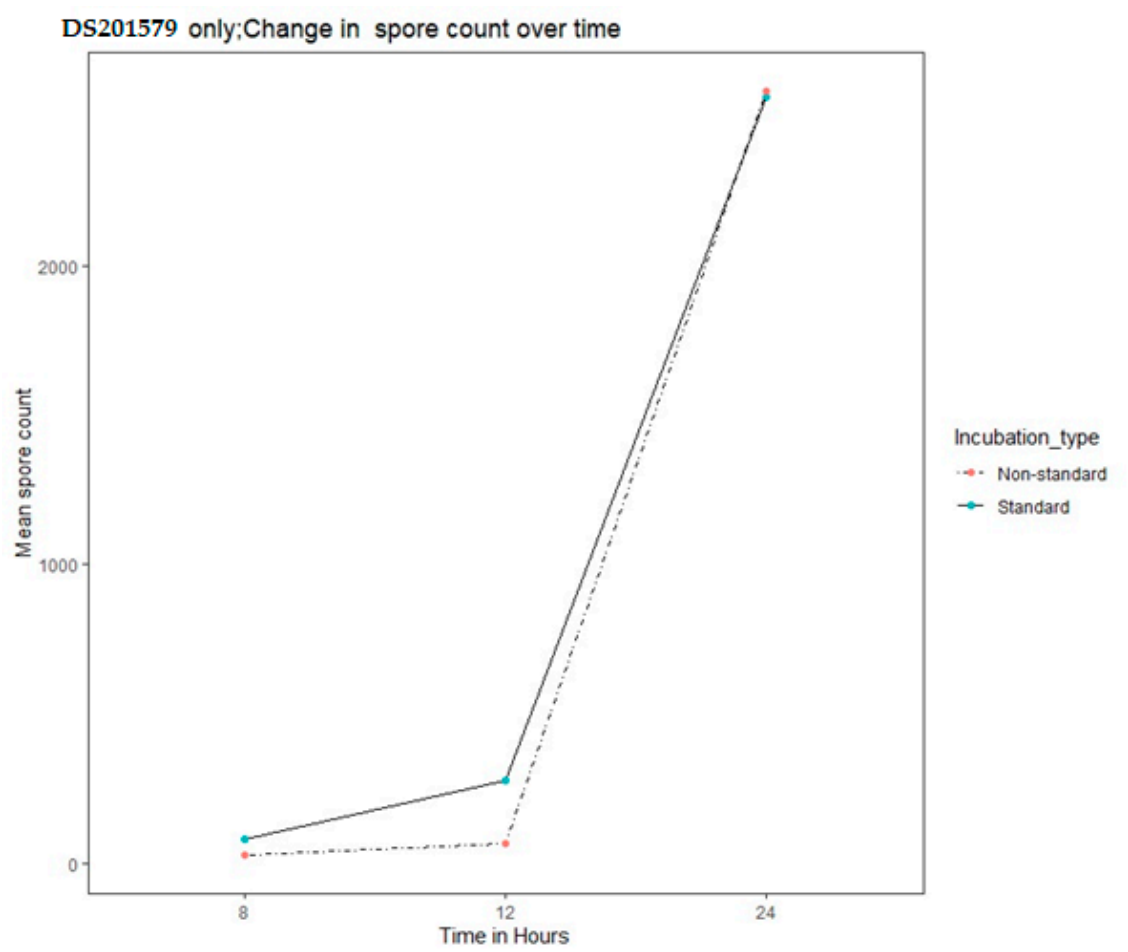

Figure A5. (A): Change in cell counts for Bacillus anthracis Sterne strain under standard conditions and carcass conditions. (B): Spore counts for Bacillus anthracis under standard conditions and carcass conditions. (C): Change in cell counts for Bacillus anthracis DS201579 strain under standard conditions and carcass conditions. (D): Change in spore counts for Bacillus anthracis Sterne strain under standard conditions and carcass conditions. (E): Change in spore counts for Bacillus anthracis DS201579 strain under standard conditions and carcass conditions.

Figure A6A-E: As with incubation type, there does not appear to be a strong effect of $\mathrm{CO}_{2}$ concentration. However, there is a difference between the bacteria types (same pattern but differences in absolute counts of cells and spores of Bacillus anthracis DS201579 and Sterne 34F2). 
A

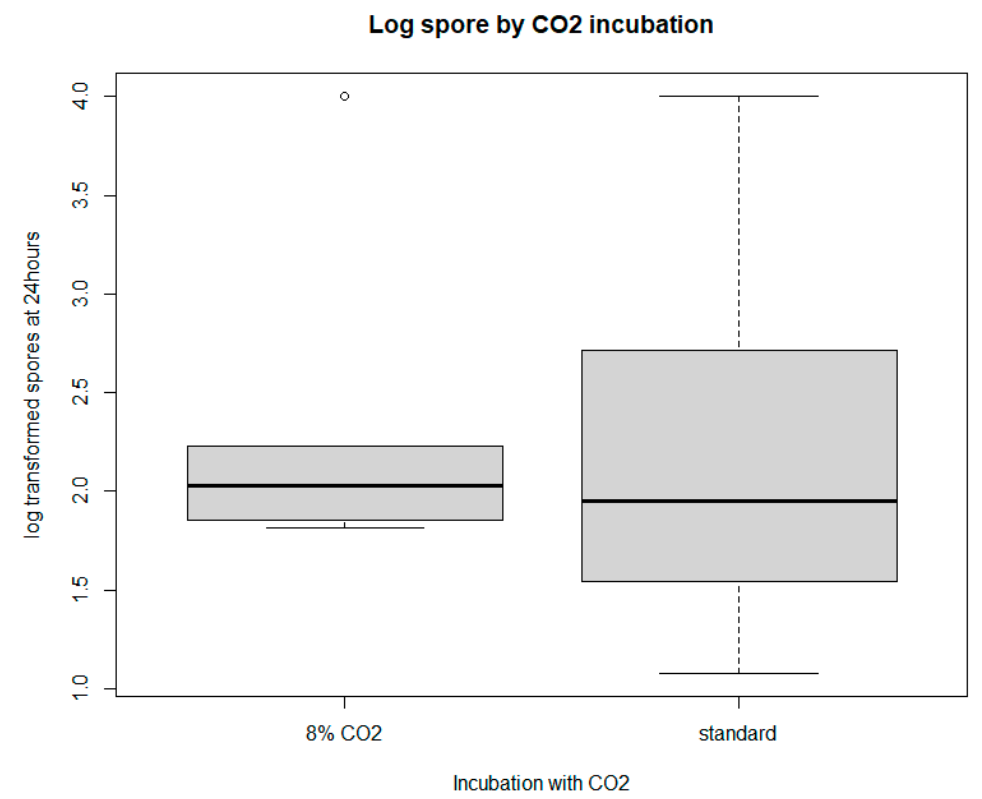

B

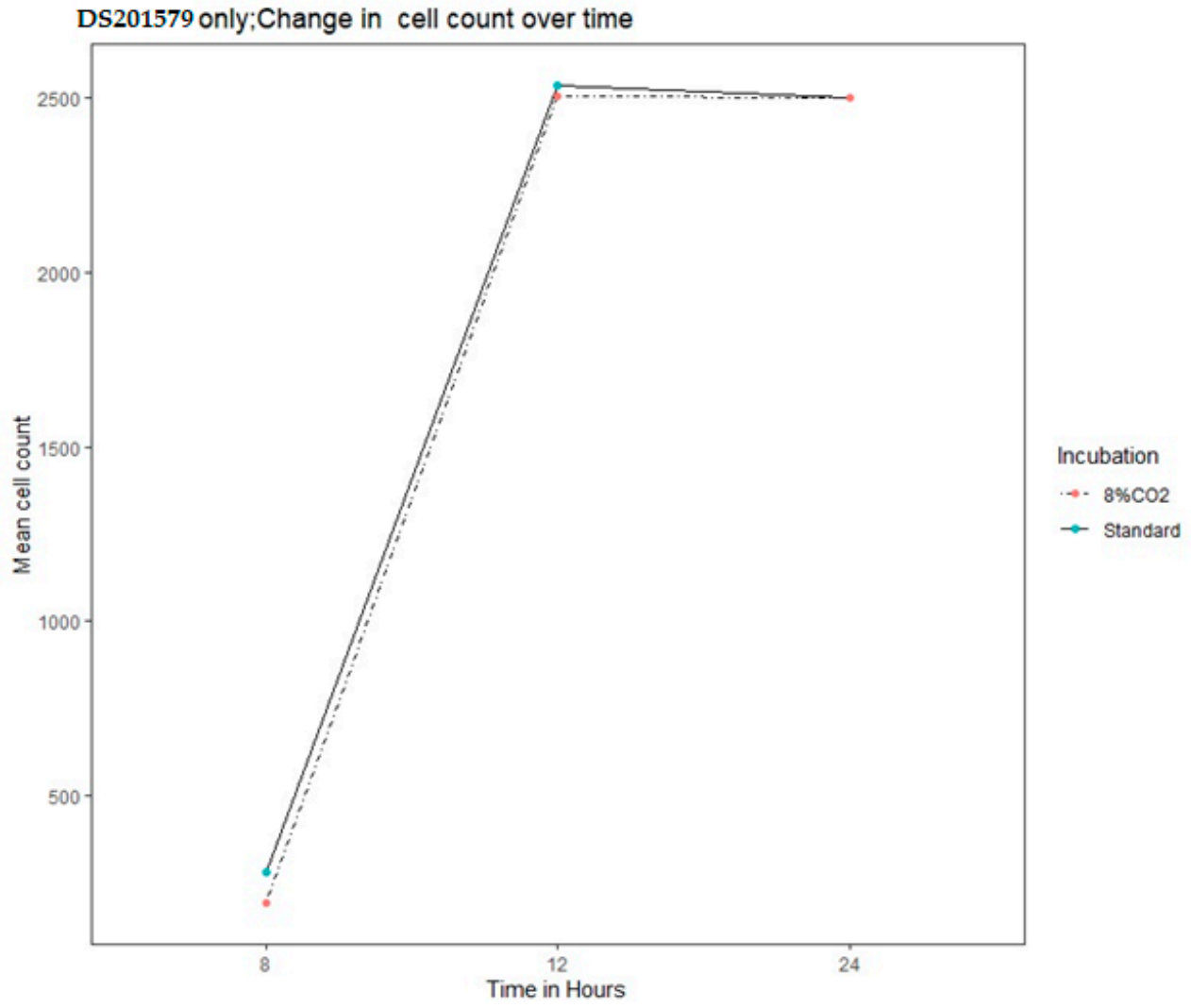

Figure A6. Cont. 
C

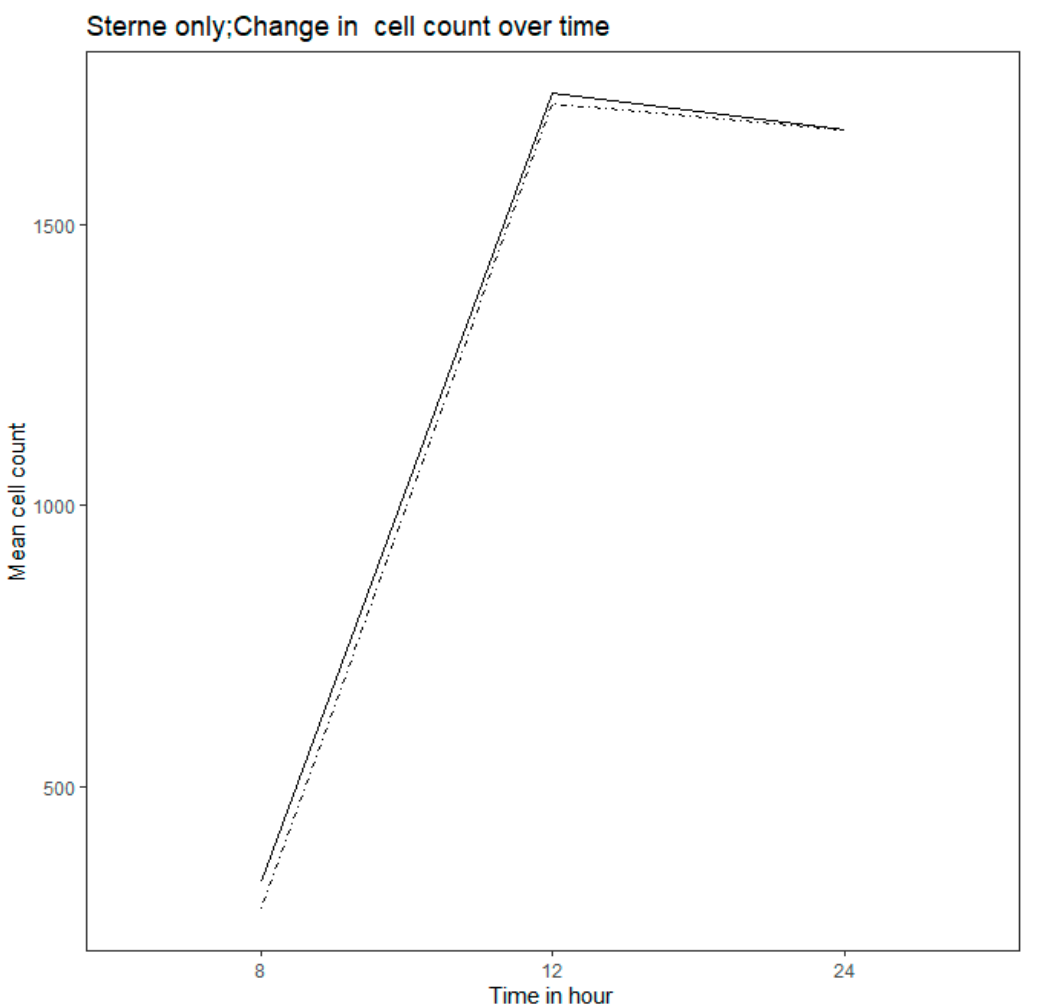

Incubation

-.. $8 \% \mathrm{CO} 2$

- Standard

D

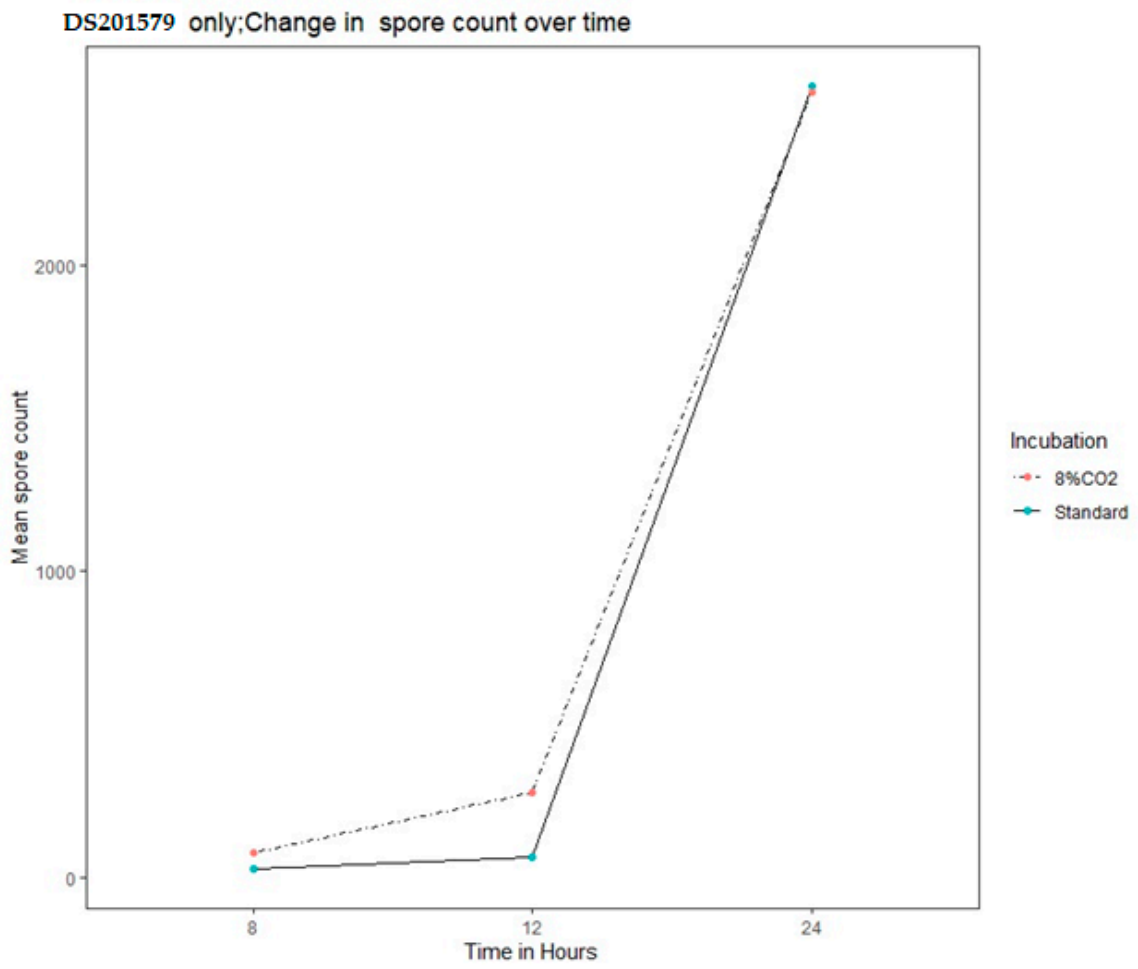

Figure A6. Cont. 
E

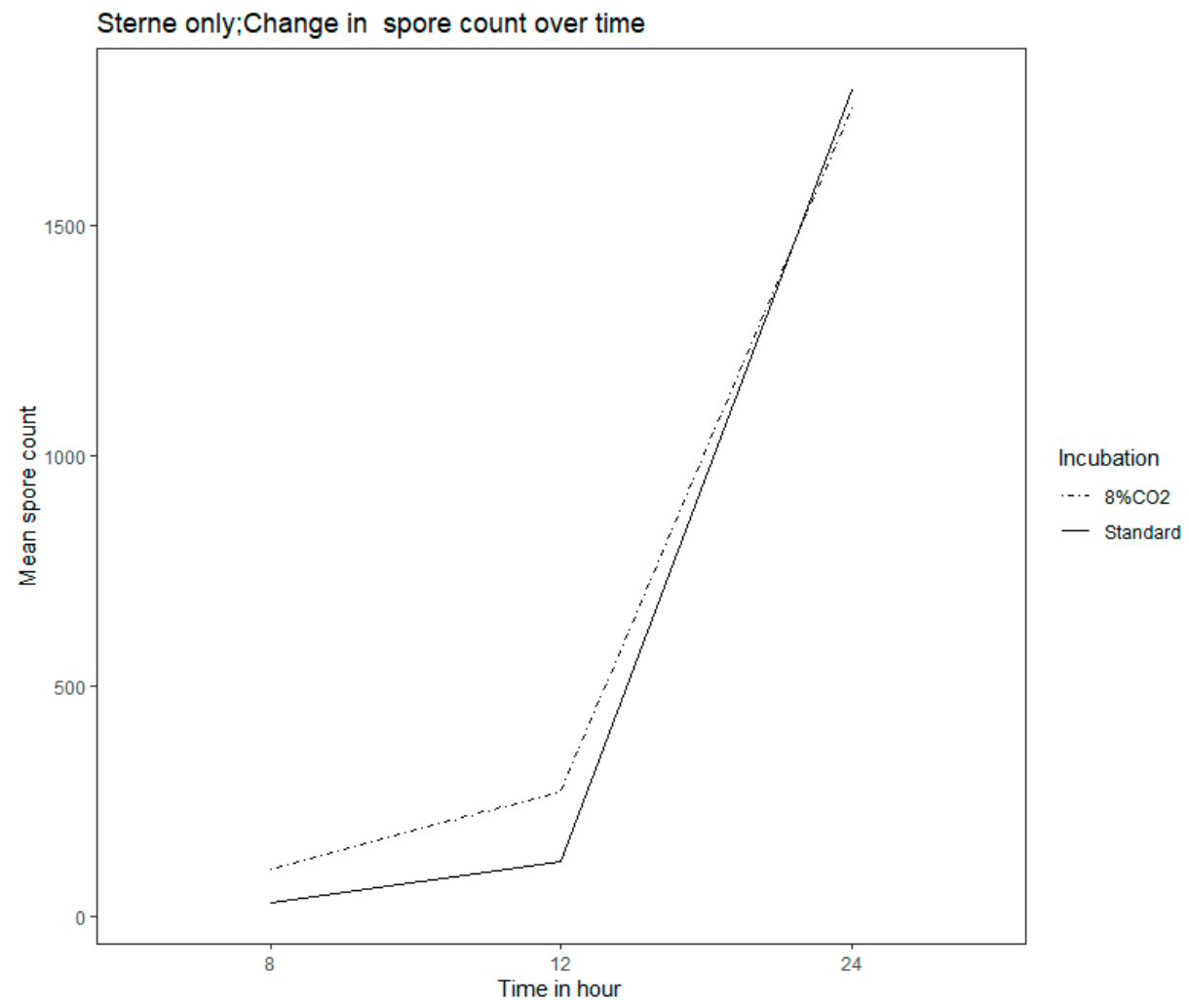

Figure A6. (A): Median spore counts for Bacillus anthracis strains under standard conditions and 8\% $\mathrm{CO}_{2}$. (B): Change in cell counts for Bacillus anthracis DS201579 strain under standard conditions and 8\% $\mathrm{CO}_{2}$. (C): Change in mean cell counts for Bacillus anthracis Sterne strain under standard conditions and $8 \% \mathrm{CO}_{2}$. (D): Change in mean spore counts for Bacillus anthracis DS201579 strain under standard conditions and $8 \% \mathrm{CO}_{2}$. (E): Change in mean spore counts for Bacillus anthracis Sterne strain under standard conditions and $8 \% \mathrm{CO}_{2}$.

Figure A7A-F: There are differences in changes in Bacillus anthracis spore and cell counts based on bicarbonate treatment. Those with bicarbonate treatment don't produce nearly as many cells because spores do not germinate in the first place.

A

Log cell by NAHCO3 incubation

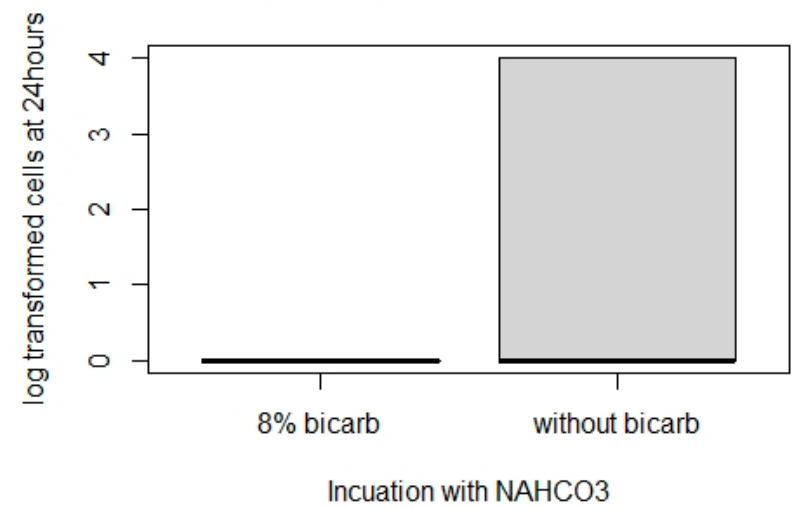

Figure A7. Cont. 
B

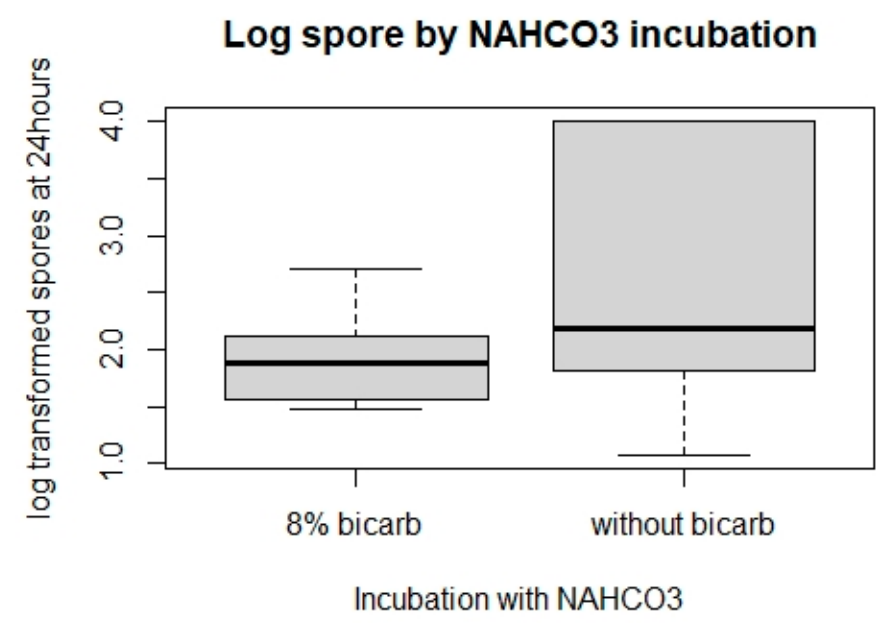

C

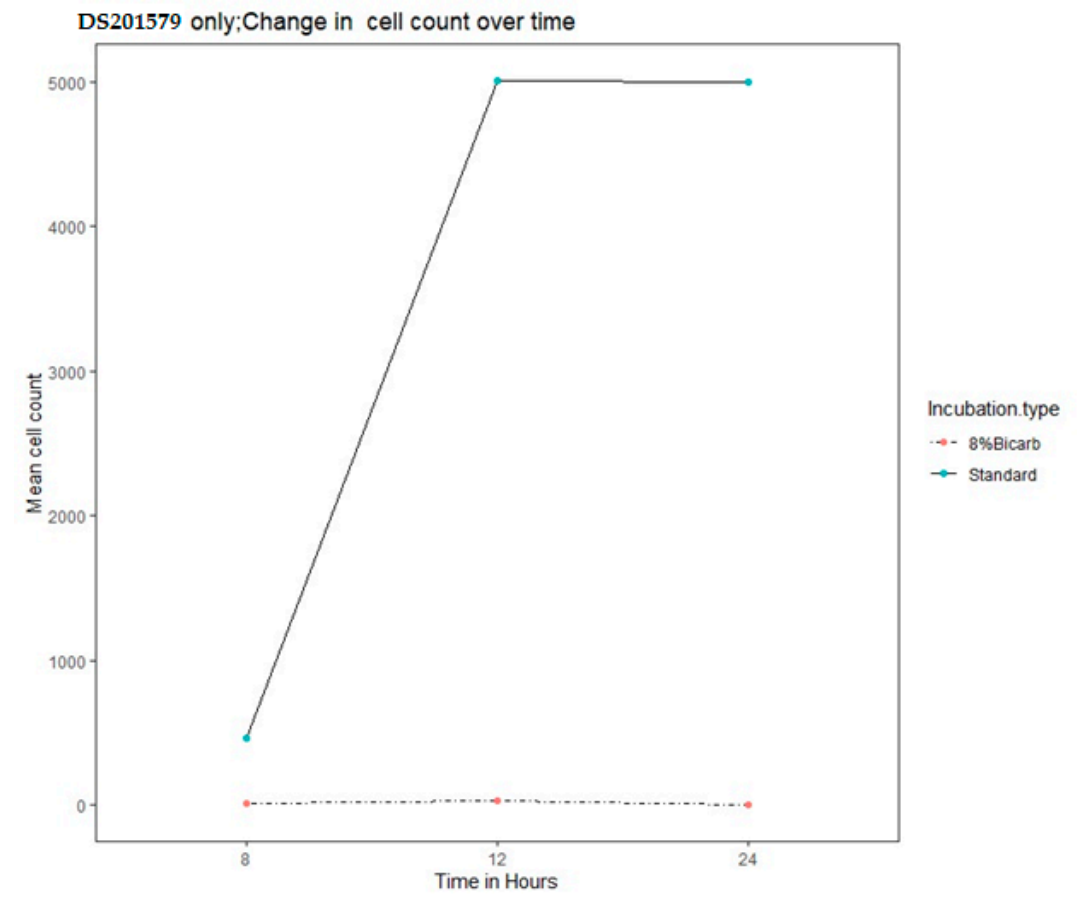

Figure A7. Cont. 
D

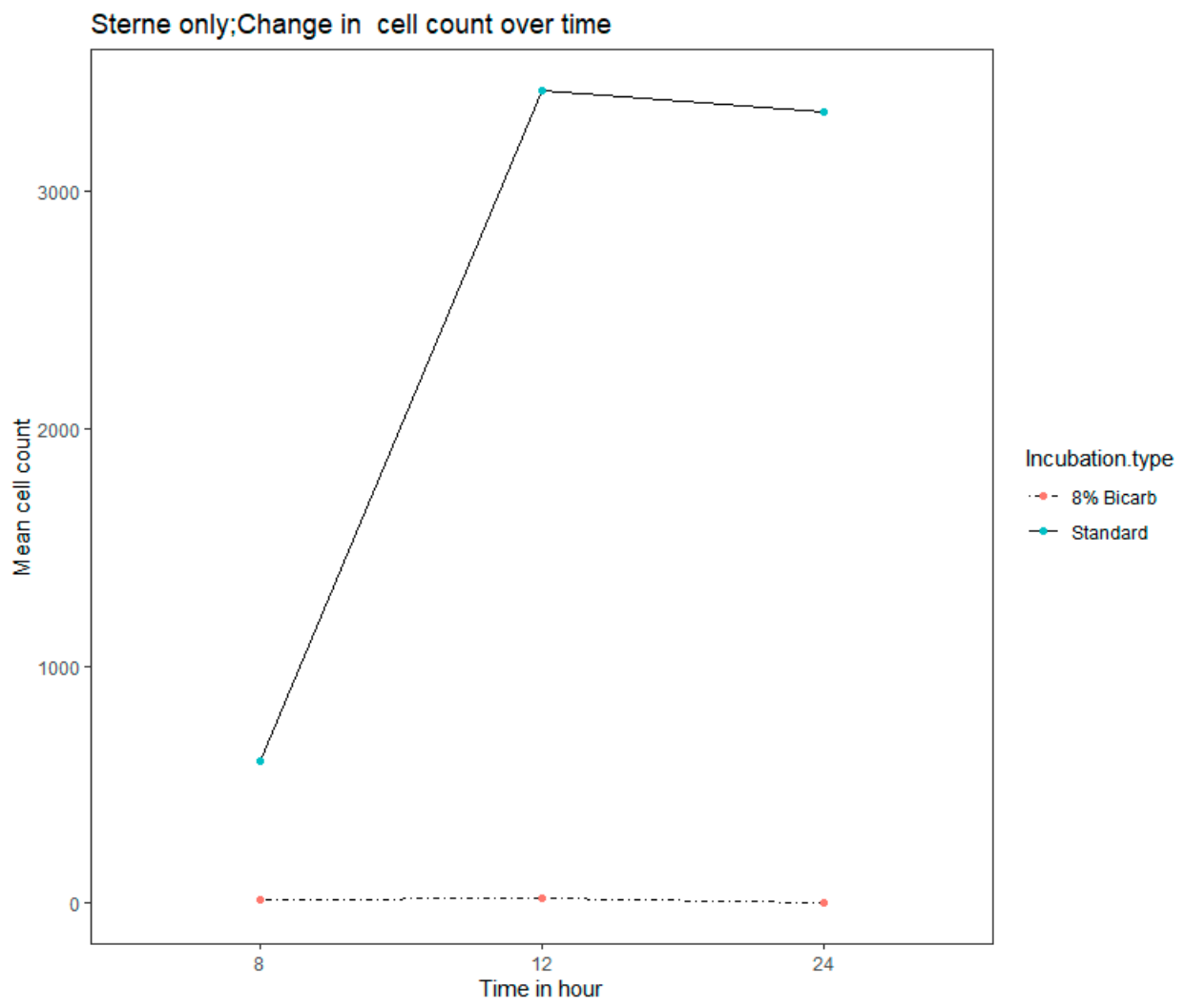

E

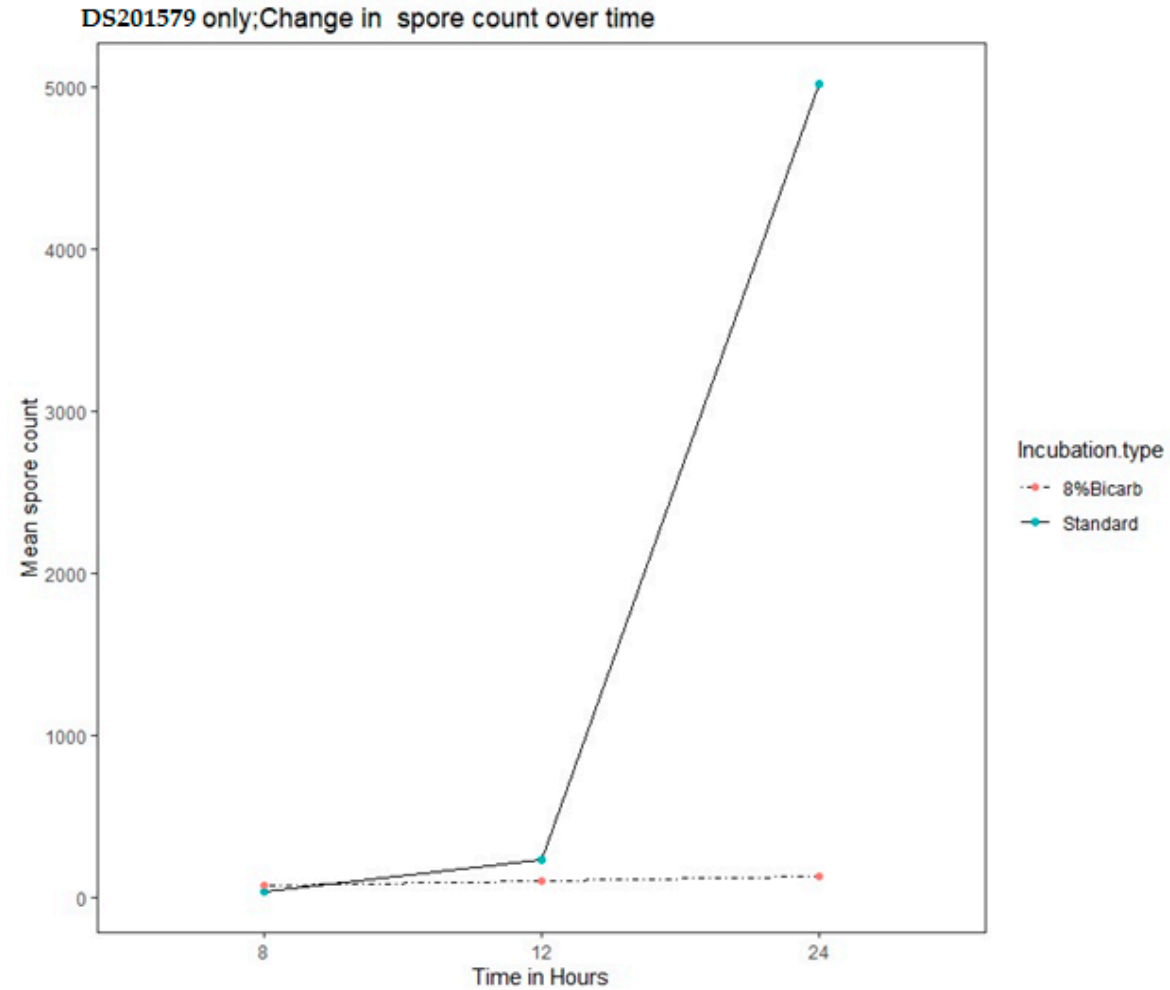

Figure A7. Cont. 


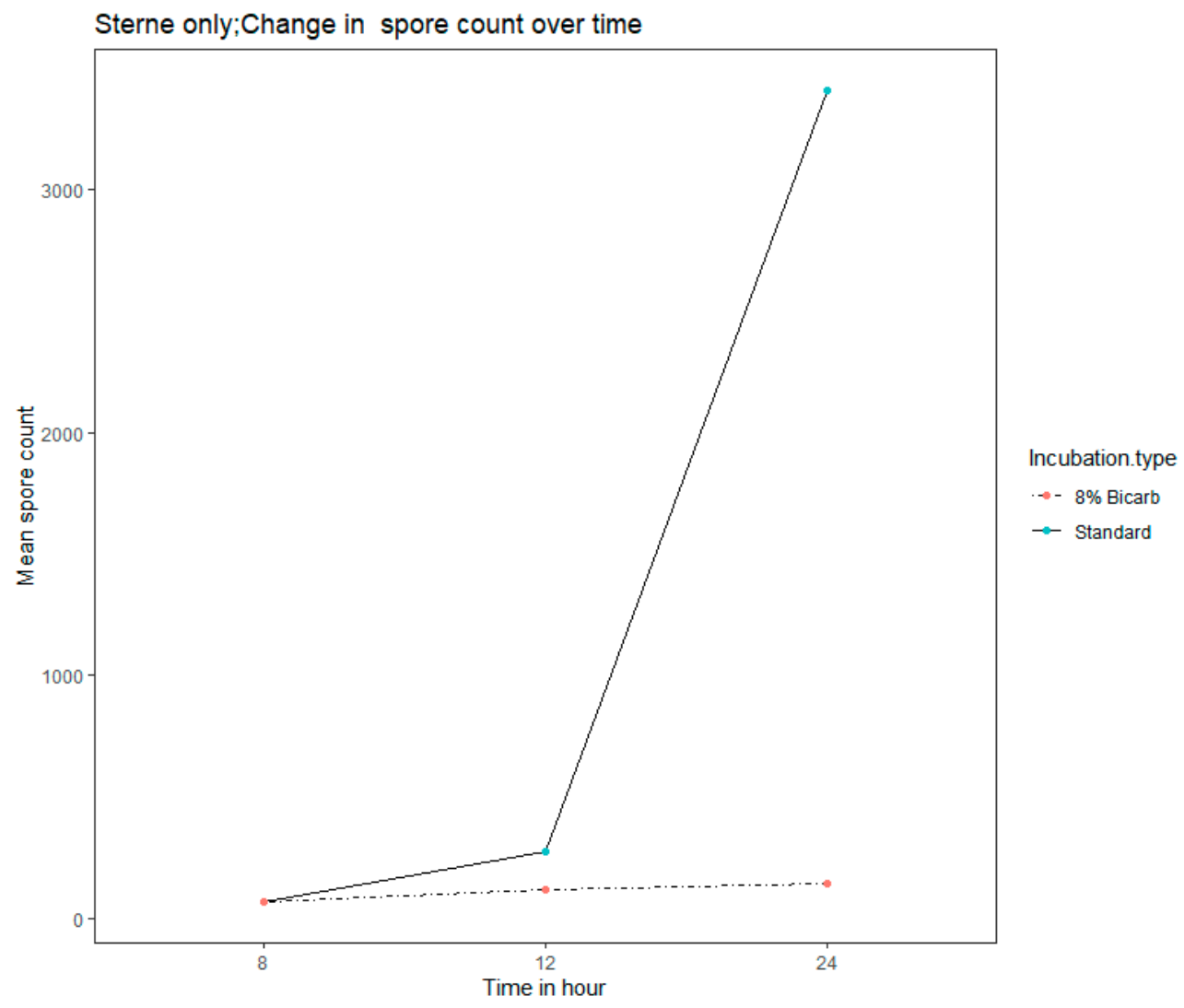

Figure A7. (A): Cell counts for Bacillus anthracis under standard conditions and with bicarbonate treatment. (B): Spore counts for Bacillus anthracis under standard conditions and with bicarbonate treatment. (C): Change in cell counts for Bacillus anthracis DS201579 under standard conditions and with bicarbonate treatment. (D): Change in cell counts for Bacillus anthracis Sterne under standard conditions and with bicarbonate treatment. (E): Change in spore counts for Bacillus anthracis DS201579 under standard conditions and with bicarbonate treatment. (F): Change in spore counts for Bacillus anthracis Sterne under standard conditions and with bicarbonate treatment.

\section{References}

1. Sterne, M. Variation in Bacillus anthracis. Onderstepoort J. Vet. Res. 1937, 8, 271-349.

2. Turnbull, P.C.B. Anthrax in Humans and Animals; World Health Organization: Geneva, Switzerland, 2008.

3. Bengis, R. An update on anthrax in wildlife in the Kruger National Park. In Proceedings of the 49th Annual Wildlife Diseases Association Conference, Orlando, FL, USA, 4 June 2000.

4. Bengis, R.; Grant, R.; De Vos, V. Wildlife diseases and veterinary controls: A savanna ecosystem perspective. In The Kruger Experience: Ecology and Management of Savanna Heterogeneity; Island Press: Washington, DC, USA, 2003; pp. 349-369.

5. De Vos, V.; Turnbull, P.C.B. Anthrax. In Infectious Diseases of Livestock, 3rd ed.; Coetzer, J.A.W., Tustin, R.C., Eds.; Oxford Univ. Press: Cape Town, South Africa, 2004; pp. 1788-1811.

6. De Vos, V.; Van Rooyen, G.L.; Kloppers, J.J. Anthrax immunization of free ranging roan antelope Hippotragus equinus in Kruger National Park. Koedoe 1973, 16, 11-25. [CrossRef]

7. Odendaal, M.W.; Pieterson, P.M.; De Vos, V.; Botha, A.D. The antibiotic sensitivity patterns of Bacillus anthracis isolated from the Kruger National Park. Onderstepoort J. Vet. Res. 1991, 58, 17-19. [PubMed]

8. Hoffmaster, A.R.; Ravel, J.; Rasko, D.A.; Chapman, G.D.; Chute, M.D.; Marston, C.K.; De, B.K.; Sacchi, C.T.; Fitzgerald, C.; Mayer, L.W.; et al. Identification of anthrax toxin genes in a Bacillus cereus associated with an illness resembling inhalation anthrax. Proc. Natl. Acad. Sci. USA 2004, 101, 8449-8454. [CrossRef] 
9. Klee, S.R.; Brzuszkiewicz, E.B.; Nattermann, H.; Bruggemann, H.; Dupke, S.; Wollherr, A.; Franz, T.; Pauli, G.; Appel, B.; Liebl, W.; et al. The genome of a Bacillus isolate causing anthrax in chimpanzees combines chromosomal properties of B. cereus with B. anthracis virulence plasmids. PLoS ONE 2010, 5, e10986. [CrossRef]

10. Papazisi, L.; Rasko, D.A.; Ratnayake, S.; Bock, G.R.; Remortel, B.G.; Appalla, L.; Liu, J.; Dracheva, T.; Braisted, J.C.; Shallom, S.; et al. Investigating the genome diversity of B. cereus and evolutionary aspects of B. anthracis emergence. Genomics 2011, 98, 26-39. [CrossRef]

11. Leppla, S.H. Anthrax toxin edema factor: A bacterial adenylate cyclase that increases cyclic AMP concentrations of eukaryotic cells. Proc. Natl. Acad. Sci. USA 1982, 79, 3162-3166. [CrossRef]

12. Park, S.; Leppla, S.H. Optimized production and purification of Bacillus anthracis lethal factor. Protein Expr. Purif. 2000, 18, 293-302. [CrossRef]

13. Green, B.; Battisti, L.; Koehler, T.; Thorne, C.; Ivins, B. Demonstration of a capsule plasmid in Bacillus anthracis. Infect. Immun. 1985, 49, 291-297. [CrossRef]

14. Sozhamannan, S.; Chute, M.D.; Mcafee, F.D.; Fouts, D.E.; Akmal, A.; Galloway, D.R.; Mateczun, A.; Baillie, L.W.; Read, T.D. The Bacillus anthracis chromosome contains four conserved, excision-proficient, putative prophages. BMC Microbiol. 2006, 6, 34. [CrossRef]

15. Pienaar, U.D.V. 'N uitbraak van Miltsiekteonder wild in die Nasionale Kruger wildtuin. Koedoe 1960, 3, 238-251. [CrossRef]

16. Smith, K.L.; Devos, V.; Bryden, H.; Price, L.B.; Hugh-Jones, M.E.; Keim, P. Bacillus anthracis diversity in Kruger National Park. J. Clin. Microbiol. 2000, 38, 3780-3784. [CrossRef] [PubMed]

17. Saile, E.; Koehler, T.M. Bacillus anthracis multiplication, persistence, and genetic exchange in the rhizosphere of grass plants. Appl. Environ. Microbiol. 2006, 72, 3168-3174. [CrossRef]

18. Schuch, R.; Fischetti, V.A. The secret life of the anthrax agent Bacillus anthracis: Bacteriophage-mediated ecological adaptations. PLoS ONE 2009, 4, e6532. [CrossRef]

19. Van Ness, G.B. Ecology of anthrax. Science 1971, 172, 1303-1307. [CrossRef] [PubMed]

20. Lee, K.; Costerton, J.W.; Ravel, J.; Auerbach, R.K.; Wagner, D.M.; Keim, P.; Leid, J.G. Phenotypic and functional characterization of Bacillus anthracis biofilms. Microbiology 2007, 153, 1693-1701. [CrossRef]

21. Ackermann, H.-W.; Audurier, A.; Berthiaume, L.; Jones, L.A.; Mayo, J.A.; Vidaver, A.K. Guidelines for bacteriophage characterization. Adv. Virus Res. 1978, 23, 1-24.

22. Ackermann, H.-W.; Azizbekyan, R.; Bernier, R.; De Barjac, H.; Saindoux, S.; Valéro, J.-R.; Yu, M.-X. Phage typing of Bacillus subtilis and B. thuringiensis. Res. Microbiol. 1995, 146, 643-657. [CrossRef]

23. Ackermann, H.W. Bacteriophage taxonomy. Microbiol. Aust. 2011, 32, 90-94. [CrossRef]

24. Cowles, P.B. A bacteriophage for B. anthracis. J. Bacteriol. 1931, 21, 161. [CrossRef]

25. Bertani, G. Studies on Lysogenesis I.: The Mode of Phage Liberation by Lysogenic Escherichia coli 1. J. Bacterial. 1951, 62, 293. [CrossRef]

26. Hargreaves, K.R.; Kropinski, A.M.; Clokie, M.R.J. Bacteriophage behavioral ecology: How phages alter their bacterial host's habits. Bacteriophage 2014, 4, e29866. [CrossRef] [PubMed]

27. Adams, M.H. Bacteriophages. In Bacteriophages; Interscience Publ, Inc.: New York, NY, USA, 1959; pp. $352-353$.

28. Letarov, A.; Kulikov, E. The bacteriophages in human- and animal body-associated microbial communities. J. Appl. Microbiol. 2009, 107, 1-13. [CrossRef] [PubMed]

29. Fouts, D.E.; Rasko, D.A.; Cer, R.Z.; Jiang, L.; Fedorova, N.B.; Shvartsbeyn, A.; Vamathevan, J.J.; Tallon, L.; Althoff, R.; Arbogast, T.S.; et al. Sequencing Bacillus anthracis typing phages gamma and cherry reveals a common ancestry. J. Bacteriol. 2006, 188, 3402-3408. [CrossRef]

30. Sulakvelidze, A.; Morris, J.G.; Alavidze, Z.; Pasternack, G.R.; Brown, T.C. Method and Device for Sanitation Using Bacteriophages. U.S. Patent 6,699,701, 2 March 2004.

31. Walmagh, M.; Briers, Y.; Dos Santos, S.B.; Azeredo, J.; Lavigne, R. Characterization of modular bacteriophage endolysins from Myoviridae phages OBP, 201phi2-1 and PVP-SE1. PLoS ONE 2012, 7, e36991. [CrossRef]

32. Demay, R.M. Practical Principles of Cytopathology; ASCP Press: Chicago, IL, USA, 1999; p. 213.

33. Kropinski, A.M.; Mazzocco, A.; Waddell, T.E.; Lingohr, E.; Johnson, R.P. Enumeration of bacteriophages by double agar overlay plaque assay. In Bacteriophages: Methods and Protocols, Volume 1: Isolation, Characterization, and Interactions; Humana Press: Totowa, NJ, USA, 2009; pp. 69-76.

34. Høyland-Kroghsbo, N.M.; Mærkedahl, R.B.; Svenningsen, S.L. A quorum-sensing-induced bacteriophage defense mechanism. MBio 2013, 4, e00362-12. [CrossRef] 
35. Koehler, T.M. Bacillus anthracis Physiology and Genetics. Mol. Asp. Med. 2009, 30, 386-396. [CrossRef]

36. R Core Team. R: A language and environment for statistical computing; R Foundation for Statistical Computing: Vienna, Austria, 2017; Available online: http://www.R-project.org/ (accessed on 13 May 2020).

37. Wilson, K. Preparation of genomic DNA from bacteria. Curr. Protoc. Mol. Biol. 1987, 56, 2-4. [CrossRef]

38. Boom, R.; Sol, C.; Salimans, M.; Jansen, C.; Wertheim-Van Dillen, P.; Van Der Noordaa, J. Rapid and simple method for purification of nucleic acids. J. Clin. Microbiol. 1990, 28, 495-503. [CrossRef]

39. Andrews, S. FastQC: A Quality Control Tool for High throughput Sequence Data. Reference Source. 2010. Available online: http://www.bioinformatics.babraham.ac.uk/projects/fastqc (accessed on 15 April 2020).

40. Altschul, S.F.; Gish, W.; Miller, W.; Myers, E.W.; Lipman, D.J. Basic local alignment search tool. J. Mol. Biol. 1990, 215, 403-410. [CrossRef]

41. Darling, A.C.; Mau, B.; Blattner, F.R.; Perna, N.T. Mauve: Multiple alignment of conserved genomic sequence with rearrangements. Genome Res. 2004, 14, 1394-1403. [CrossRef] [PubMed]

42. Arndt, D.; Grant, J.; Marcu, A.; Sajed, T.; Pon, A.; Liang, Y.; Wishart, D.S. PHASTER: A better, faster version of the PHAST phage search tool. Nucleic Acids Res. 2016, 44, W16-W21. [CrossRef] [PubMed]

43. Grant, J.R.; Stothard, P. The CGView Server: A comparative genomics tool for circular genomes. Nucleic Acids Res. 2008, 36, W181-W184. [CrossRef] [PubMed]

44. Katoh, K.; Standley, D.M. MAFFT multiple sequence alignment software version 7: Improvements in performance and usability. Mol. Biol. Evol. 2013, 30, 772-780. [CrossRef]

45. Kumar, S.; Stecher, G.; Tamura, K. MEGA7: Molecular Evolutionary Genetics Analysis version 7.0. Mol. Biol. Evol. 2016, 33, 1870-1874. [CrossRef]

46. Zhao, Y.; Wu, J.; Yang, J.; Sun, S.; Xiao, J.; Yu, J. PGAP: Pan-genomes analysis pipeline. Bioinformatics 2012, 28, 416-418. [CrossRef]

47. Aziz, R.K.; Bartels, D.; Best, A.A.; Dejongh, M.; Disz, T.; Edwards, R.A.; Formsma, K.; Gerdes, S.; Glass, E.M.; Kubal, M. The RAST Server: Rapid annotations using subsystems technology. BMC Genom. 2008, 9, 75. [CrossRef]

48. Brown, E.R.; Cherry, W.B. Specific identification of Bacillus anthracis by means of a variant bacteriophage. J. Infect. Dis. 1955, 96, 34-39. [CrossRef]

49. Sirard, J.-C.; Mock, M.; Fouet, A. The three Bacillus anthracis toxin genes are co-ordinately regulated by bicarbonate and temperature. J. Bacteriol. Res. 1994, 176, 5188-5192. [CrossRef]

50. Klumpp, J.; Beyer, W.; Loessner, M.J. Direct Submission of Bacillus Phage W.Ph., Complete Genome; Acession: NC_016563; National Center for Biotechnology Information: Bethesda, MD, USA, 2012.

51. Klumpp, J.; Schmuki, M.; Sozhamannan, S.; Beyer, W.; Fouts, D.E.; Bernbach, V.; Calendar, R.; Loessner, M.J. The odd one out: Bacillus ACT bacteriophage CP-51 exhibits unusual properties compared to related Spounavirinae W.Ph. and Bastille. Virology 2014, 462, 299-308. [CrossRef]

52. Sonenshein, A.L.; Roscoe, D.H. The course of phage Øe infection in sporulating cells of Bacillus subtilis strain 3610. Virology 1969, 39, 265-276. [CrossRef]

53. Cowles, P.B. The recovery of bacteriophage from filtrates derived from heated spore-suspensions. J. Bacteriol. 1931, 22, 119. [CrossRef] [PubMed]

54. Takahashi, I. Incorporation of bacteriophage genome by spores of Bacillus subtilis. J. Bacteriol. Res. 1964, 87, 1499-1502. [CrossRef]

55. Tait, K.; Skillman, L.; Sutherland, I. The efficacy of bacteriophage as a method of biofilm eradication. Biofouling 2002, 18, 305-311. [CrossRef]

56. Jończyk, E.; Kłak, M.; Międzybrodzki, R.; Górski, A. The influence of external factors on bacteriophages-review. Folia Microbiol. 2011, 56, 191-200. [CrossRef]

57. Van Elsas, J.; Penido, E. Characterization of a new Bacillus megaterium bacteriophage, MJ-1, from tropical soil. Antonie Leeuwenhoek 1982, 48, 365-371. [CrossRef]

58. Drysdale, M.; Bourgogne, A.; Koehler, T.M. Transcriptional analysis of the Bacillus anthracis capsule regulators. J. Bacteriol. 2005, 187, 5108-5114. [CrossRef]

59. Meynell, E.; Meynell, G.G. The Roles of Serum and Carbon Dioxide in Capsule Formation by Bacillus anthracis. J. Gen. Microbiol. 1964, 34, 153-164. [CrossRef]

60. Enfors, S.O.; Molin, G. The influence of high concentrations of carbon dioxide on the germination of bacterial spores. J. Appl. Bacteriol. 1978, 45, 279-285. [CrossRef] 
61. Hachisuka, Y.; Kato, N.; Asano, N. Inhibitory effect of sodium bicarbonate and sodium carbonate on spore germination of Bacillus subtilis. J. Bacteriol. 1956, 71, 250-251. [CrossRef]

62. Luria, S.; Human, M.L. Chromatin staining of bacteria during bacteriophage infection. J. Bacteriol. Res. 1950, 59, 551. [CrossRef]

63. Silpe, J.E.; Bassler, B.L. A host-produced quorum-sensing autoinducer controls a phage lysis-lysogeny decision. Cell 2019, 176, 1-2. [CrossRef] [PubMed]

64. Carfi, A.; Pares, S.; Duée, E.; Galleni, M.; Duez, C.; Frère, J.M.; Dideberg, O. The 3-D structure of a zinc metallo-beta-lactamase from Bacillus cereus reveals a new type of protein fold. EMBO J. 1995, 14, 4914-4921. [CrossRef] [PubMed]

65. Payne, D. Metallo- $\beta$-lactamases-New therapeutic challenge. J. Med. Microbiol. 1993, 39, 93-99. [CrossRef] [PubMed]

66. Smith, K.C.; Castro-Nallar, E.; Fisher, J.N.; Breakwell, D.P.; Grose, J.H.; Burnett, S.H. Phage cluster relationships identified through single gene analysis. BMC Genom. 2013, 14, 410. [CrossRef]

67. Ravel, J.; Jiang, L.; Stanley, S.T.; Wilson, M.R.; Decker, R.S.; Read, T.D.; Worsham, P.; Keim, P.S.; Salzberg, S.L.; Fraser-Liggett, C.M. The complete genome sequence of Bacillus anthracis Ames "Ancestor". J. Bacteriol. 2009, 191, 445-446. [CrossRef]

68. Rasko, D.A.; Altherr, M.R.; Han, C.S.; Ravel, J. Genomics of the Bacillus cereus group of organisms. FEMS Microbiol. Rev. 2005, 29, 303-329.

69. Zwick, M.E.; Joseph, S.J.; Didelot, X.; Chen, P.E.; Bishop-Lilly, K.A.; Stewart, A.C.; Willner, K.; Nolan, N.; Lentz, S.; Thomason, M.K.; et al. Genomic characterization of the Bacillus cereus sensulato species: Backdrop to the evolution of Bacillus anthracis. Genome Res. 2012, 22, 1512-1524. [CrossRef]

70. Hyman, P.; Abedon, S.T. Chapter 7: Bacteriophage Host Range and Bacterial Resistance. In Advances in Applied Microbiology; Academic Press: Cambridge, MA, USA, 2010; pp. 217-248.

71. Seed, K.D. Battling Phages: How Bacteria Defend against Viral Attack. PLoS Pathog. 2015, 11, e1004847. [CrossRef]

72. Al-Shayeb, B.; Sachdeva, R.; Chen, L.X.; Ward, F.; Munk, P.; Devoto, A.; Castelle, C.J.; Olm, M.R.; Bouma-Gregson, K.; Amano, Y.; et al. Clades of huge phages from across Earth's ecosystems. Nature 2020, 578, 425-431. [CrossRef] 